\title{
Analisis Risiko Pembiayaan Syariah Pada Sektor Pertanian
}

\author{
Risk Analysis of Islamic Finance in Agricultural Sector
}

\author{
Khonsa Tsabita \\ Department of Economics, Faculty of Economics and Management Science, \\ International Islamic University Malaysia, Gombak, Kuala Lumpur, Malaysia \\ E-mail: khonsabita@gmail.com, Mobile: +6012925 7255
}

\begin{abstract}
One of the main problems of agricultural sector in Indonesia is the lack of financial support. There are many financing programs which available to overcome this problem, but this problem still persist. Thus, the alternative financing scheme such as Islamic financing that concern on risk sharing concept rather than profit, is a feasible solution. Moreover, the increase of Islamic financing on agricultural sector requires many studies. One of them is about financing risk analysis as well as risk management instruments and systems. This research is applied at BPRS (Islamic Rural Bank) Amanah Ummah, Leuwiliang, Bogor, Indonesia, which provides financing for agricultural business. Thus, this research is focused on analyzing Islamic financing risk and measuring potential loss. In addition, this Islamic financing risk is analyzed with Enterprise Risk Management (ERM) framework method and the potential loss is measured with creditrisk+ method. Overall, this research contributes to literatures on Islamic financing in agricultural sector and provides ground-study related to financing risk analysis on Islamic microfinance institutions.
\end{abstract}

Keywords: Agriculture, Enterprise Risk Management, Islamic Financing

\begin{abstract}
Abstrak. Salah satu permasalahan utama pada sektor pertanian di Indonesia adalah pembiayaan. Beberapa model pembiayaan yang sudah ada dianggap belum sesuai dengan sektor ini. Model pembiayaan syariah merupakan salah satu model pembiayaan alternatif yang dianggap sesuai untuk pertanian karena menggunakan prinsip bagi hasil, keadilan, dan kepercayaan. Dibutuhkan banyak kajian dalam mendukung realisasi peningkatan alokasi pembiayaan syariah ke sektor pertanian di Indonesia dan salah satu kajiannya yaitu mengenai risiko pembiayaan syariah pertanian. Penelitian ini mengambil studi kasus di BPRS Amanah Ammah, Leuwiliang, Bogor yang merupakan salah satu lembaga pembiayaan syariah yang mengalokasikan pembiayaannya ke sektor pertanian. Tujuan penelitian ini adalah menganalisis risiko pembiayaan syariah pertanian dan menghitung potensi kerugian pembiayaan syariah pertanian. Analisis risiko pembiayaan syariah dilakukan dengan menggunakan tahapan metode Enterprise Risk Management (ERM) sedangkan potensi kerugian pembiayaan syariah untuk pertanian dihitung dengan metode creditrisk+. Hasil penelitian ini menunjukkan bahwa risiko utama dari pembiayaan syariah pada sektor pertanian adalah nasabah gagal bayar karena karakter buruk/faktor moral hazard. Tindakan mitigasi risiko yang dapat dilakukan adalah melakukan rescheduling, restrukturisasi, dan pencairan jaminan nasabah. Penelitian ini dapat dijadikan sebagai kajian studi lapang mengenai risiko pembiayaan yang terdapat pada lembaga keuangan syariah mikro dan tinjauan pustaka di bidang pembiayaan syariah pertanian.
\end{abstract}

Kata kunci: Enterprise Risk Management, Pembiayaan Syariah, Pertanian

\section{Pendahuluan}

Sektor pertanian memiliki peran yang sangat strategis dalam pembangunan nasional dan perekonomian Indonesia. Peran tersebut dicirikan oleh 2 faktor penting. Pertama, jumlah tenaga kerja yang diserap oleh sektor pertanian. Badan Pusat Statistik (2013) melaporkan bahwa dari total penduduk yang bekerja pada lapangan pekerjaan utama, terdapat sekitar 38.88 juta atau sekitar $35.09 \%$ yang bekerja di sektor pertanian. Kedua, luas lahan yang digunakan untuk pertanian yaitu sekitar $71.33 \%$ dari seluruh luas lahan di Indonesia (Hafidhuddin dan Syukur 2008). 
Sumbangan sektor pertanian terhadap produk domestik bruto (PDB) tidak sebanding dengan jumlah tenaga kerja dan luas lahan. Badan Pusat Statistik (2013) memperlihatkan jumlah PDB Indonesia atas dasar harga berlaku sebesar Rp7 427.1 triliun. Sektor pertanian, peternakan, kehutanan, dan perikanan memberikan kontribusi sebesar Rp1 093.5 triliun (14.70\% dari total PDB). Data tersebut memperlihatkan bahwa kontribusi PDB dari sektor pertanian masih lebih rendah dibandingkan dengan sektor industri. Di samping itu, besaran persentase PDB sektor pertanian (14.70\%) masih jauh lebih rendah dibandingkan besarnya persentase penyerapan tenaga kerja oleh sektor pertanian $(35.86 \%)$. Hal tersebut menunjukkan bahwa masih terdapat banyak permasalahan dalam sektor pertanian, salah satunya yaitu masalah permodalan (Direktorat Pembiayaan Kementerian Pertanian 2011).

Sektor pertanian dikenal sebagai sektor usaha yang cukup berisiko sehingga minat lembaga pembiayaan untuk mendanai usaha sektor ini relatif rendah. Beberapa hasil kajian menunjukkan bahwa proporsi kredit perbankan untuk sektor pertanian masih jauh di bawah pembiayaan sektor perindustrian, perdagangan, restoran dan hotel (PHR), pengangkutan, dan sektor ekonomi lain. Salah satu penyebab rendahnya alokasi kredit di sektor pertanian adalah tidak adanya perlakuan khusus dari pihak lembaga pembiayaan untuk sektor pertanian. Selama ini, kebijakan untuk pembiayaan pertanian diintegrasikan dengan pembiayaan nonpertanian sehingga pembiayaan pertanian menjadi tidak kompetitif. Untuk lebih menjamin ketersediaan modal usaha bagi pelaku bisnis pertanian, perlu dicari alternatif model pembiayaan yang sesuai dengan karakteristik usaha di sektor pertanian, yaitu model pembiayaan syariah. Model ini lebih memberikan keadilan dan berprinsip pada sistem bagi hasil, bukan pada sistem bunga yang seringkali mengakibatkan kebangkrutan pada petani/pelaku usaha pertanian.

Pembiayaan syariah adalah salah satu solusi untuk pertanian karena memakai pola bagi hasil yang aspek keadilannya akan lebih muncul daripada memakai bunga. Selain itu, pembiayaan syariah tidak hanya menyediakan permodalan bagi petani, tetapi juga akses yang mudah terhadap permodalan dinilai menjadi faktor penting dalam pembiayaan1. Selain itu, pemilihan skema pembiayaan syariah ini juga didukung dengan pertimbangan faktor demografis, mengingat sebagian besar petani di Indonesia beragama Islam. Di samping itu, secara sosiologis, sesungguhnya praktik-praktik bagi hasil sudah lama diterapkan di kalangan petani seperti maro, mertelu, gaduhan, dan sebagainya.

Sistem pembiayaan syariah di Indonesia sudah diterapkan oleh beberapa lembaga keuangan. Salah satu lembaga keuangan syariah yang perkembangannya signifikan dari tahun ke tahun dan menunjukkan performa yang baik adalah Bank Pembiayaan Rakyat Syariah (BPRS). BPRS adalah institusi keuangan yang dirancang untuk mengembangkan jasa keuangan syariah dengan fokus utama pada pengembangan usaha mikro, kecil dan menengah pada masyarakat. Munculnya BPRS yang mengalokasikan pembiayaannya untuk pertanian adalah salah satu kontribusi untuk menjawab permasalahan pertanian dalam hal permodalan. Peningkatan jumlah BPRS diharapkan mampu meningkatkan distribusi pembiayaan dalam sektor pertanian. Peningkatan jumlah BPRS di Indonesia dari tahun ke tahun dapat dilihat pada Tabel 1.

\footnotetext{
${ }^{1}$ Menurut Suswono dalam http://koranfakta.net/ekonomi/syariah/621-pembiayaan-syariahsolusi-untuk-pertanian-.html [diakses 2012 November 27]
} 
Tabel 1 Jumlah Bank Pembiayaan Rakyat Syariah (BPRS) berdasarkan lokasia

\begin{tabular}{lccccccc}
\hline \multirow{2}{*}{ Provinsi } & \multicolumn{7}{c}{ Tahun $^{\mathrm{b}}$} \\
\cline { 2 - 8 } & 2007 & 2008 & 2009 & 2010 & 2011 & 2012 & $2^{2013^{\mathrm{c}}}$ \\
\hline Jawa Barat & 28 & 28 & 27 & 28 & 27 & 27 & 27 \\
Jawa Timur & 19 & 23 & 25 & 29 & 30 & 31 & 31 \\
Jawa Tengah & 13 & 15 & 19 & 21 & 21 & 24 & 24 \\
DKI Jakarta & 1 & 1 & 2 & 2 & 2 & 2 & 2 \\
DI Yogyakarta & 6 & 9 & 9 & 10 & 11 & 11 & 11 \\
Banten & 8 & 8 & 8 & 8 & 8 & 8 & 8 \\
NAD & 5 & 6 & 7 & 10 & 10 & 10 & 10 \\
Sumatera Utara & 7 & 7 & 7 & 8 & 10 & 8 & 8 \\
Sumatera Barat & 4 & 6 & 6 & 6 & 7 & 7 & 7 \\
Provinsi Lain-Lain & 23 & 28 & 28 & 28 & 29 & 30 & 30 \\
Total di Indonesia & 114 & 131 & 138 & 150 & 155 & 158 & 158 \\
\hline
\end{tabular}

${ }^{\mathrm{a}}$ Sumber: Bank Indonesia (2013); ${ }^{\mathrm{b}}$ unit; ${ }^{\mathrm{c} J a n u a r i} 2013$

Tabel 1 menunjukkan tren yang meningkat tiap tahunnya pada jumlah BPRS yang telah beroperasi di seluruh wilayah Indonesia. Provinsi Jawa Timur tercatat sebagai wilayah yang paling banyak memiliki BPRS, yaitu sebanyak 31 unit. Selanjutnya, di posisi kedua terdapat Provinsi Jawa Barat dengan 27 unit. Jumlah BPRS yang meningkat dari tahun ke tahun memperlihatkan bahwa lembaga keuangan syariah semakin dibutuhkan oleh masyarakat.

Jika dilihat dari alokasi pembiayaan BPRS berdasarkan sektor ekonomi, pada Januari 2013, sektor pertanian menempati posisi ketiga dengan persentase $8.58 \%$ setelah sektor perdagangan dan sektor lain (Tabel 2). Tabel 2 juga menunjukkan bahwa dari tahun 2007 hingga 2012, pembiayaan BPRS untuk sektor pertanian terus meningkat. Hal ini memperlihatkan bahwa terdapat potensi pembiayaan melalui BPRS kepada sektor pertanian.

Tabel 2 Pembiayaan BPRS berdasarkan sektor ekonomi ${ }^{\mathrm{a}}$

\begin{tabular}{|c|c|c|c|c|c|c|c|c|}
\hline \multirow{2}{*}{ No. } & \multirow{2}{*}{$\begin{array}{c}\text { Lapangan } \\
\text { Pekerjaan } \\
\text { Utama }\end{array}$} & \multicolumn{7}{|c|}{ Tahun $^{\text {b }}$} \\
\hline & & 2007 & 2008 & 2009 & 2010 & 2011 & 2012 & $2013^{c}$ \\
\hline 1. & Pertanian & 24436 & 41613 & 54486 & 107129 & 223986 & 351191 & 306001 \\
\hline 2. & Pertambangan & 944 & 1287 & 998 & 905 & 2475 & 7851 & 6338 \\
\hline 3. & Perindustrian & 12447 & 15885 & 20420 & 24635 & 33781 & 31314 & 33754 \\
\hline 4. & $\begin{array}{l}\text { Listrik, Gas, } \\
\text { dan Air }\end{array}$ & 367 & 1146 & 1055 & 1569 & 2785 & 4038 & 4385 \\
\hline 5. & Konstruksi & 16051 & 26536 & 48178 & 66492 & 92603 & 125137 & 116081 \\
\hline 6. & Perdagangan & 295195 & 370907 & 486018 & 624428 & 1006448 & 1222281 & $\begin{array}{l}1264 \\
094\end{array}$ \\
\hline 7. & $\begin{array}{l}\text { Angkutan dan } \\
\text { Komunikasi }\end{array}$ & 9075 & 17697 & 17289 & 21768 & 36506 & 67423 & 66845 \\
\hline 8. & $\begin{array}{l}\text { Jasa Dunia } \\
\text { Usaha }\end{array}$ & 99050 & 140989 & 176760 & 276887 & 255311 & 264569 & 281004 \\
\hline 9. & Jasa Sosial & 6402 & 22609 & 16451 & 26564 & 91939 & 227216 & 228644 \\
\hline 10. & Lain-Lain & 422148 & 617942 & 765264 & 910060 & 930095 & 1252499 & $\begin{array}{l}1258 \\
376\end{array}$ \\
\hline & TOTAL & 886117 & 1256610 & 1586919 & 2060437 & 2675930 & 3553520 & 3565521 \\
\hline
\end{tabular}

a Sumber: Bank Indonesia (2013); ${ }^{b}$ Dalam juta rupiah; ' Januari 2013

BPRS memiliki tujuan utama untuk menumbuhkan ekonomi masyarakat atas dasar syariah Islam sebagaimana telah diatur dalam UU No 21 tahun 2008 tentang Perbankan 
Syariah. Mayoritas penduduk negara Indonesia beragama Islam sehingga kehadiran bank syariah yang diyakini prinsip-prinsip dan operasionalnya sesuai dengan syariat Islam adalah sebuah kebutuhan dan keharusan. Hal ini didasarkan bahwa Islam adalah ajaran yang tidak hanya mengatur masalah aqidah dan akhlaq, namun juga mengatur ibadah dan muamalah dalam berbagai aspek kehidupan, termasuk kehidupan sosial ekonomi ${ }^{2}$.

Bank Indonesia (2013) memperlihatkan jumlah alokasi pembiayaan untuk sektor pertanian semakin meningkat dari tahun 2007 hingga 2012. Walaupun secara proporsi pembiayaan sektor pertanian masih cenderung stagnan, peningkatan alokasi pembiayaan tersebut memperlihatkan bahwa ketertarikan dan kepercayaan untuk membiayai sektor pertanian dari lembaga keuangan syariah mengalami peningkatan. Perkembangan positif ini harus dapat dimanfaatkan dengan baik agar alokasi dan proporsi pembiayaan untuk sektor pertanian semakin meningkat bahkan menjadi fokus utama. Beberapa kajian mengenai perkembangan pembiayaan syariah untuk sektor pertanian perlu dilakukan dan salah satunya dapat ditelaah dari sisi risiko. Kajian terhadap risiko pembiayaan syariah pertanian dapat memberikan gambaran mendalam mengenai potensi risiko yang sebenarnya pada sektor pertanian sehingga dapat dijadikan acuan ke depan untuk mengoptimalkan pembiayaan syariah dalam sektor pertanian.

Aspek risiko pembiayaan dalam sebuah BPRS menjadi penting untuk digali karena umumnya risiko pembiayaan pada bank syariah memiliki tingkat risiko lebih tinggi dibandingkan risiko pembiayaan pada bank konvensional (dengan adanya sistem bagi hasil). Walaupun begitu, data historis menunjukkan bahwa bank syariah tidak pernah mengalami kebangkrutan secara finansial seperti halnya pada bank konvensional (contoh kasus: krisis ekonomi tahun 1998).

Permasalahan pertanian dalam permodalan juga dapat diatasi dengan adanya penyaluran pembiayaan dari lembaga keuangan syariah, misalnya BPRS. Namun, penyaluran pembiayaan untuk pertanian ini harus diimbangi dengan pengelolaan risiko yang terkandung dalam proses pembiayaan yang ada.

Pada penelitian kali ini, diambil salah satu lembaga keuangan syariah berupa Bank Pembiayaan Rakyat Syariah (BPRS), yaitu BPRS Amanah Ummah, Leuwiliang, Bogor yang menyalurkan dananya ke sektor pertanian. Alasan pemilihan tempat ini karena BPRS Amanah Ummah merupakan salah satu lembaga keuangan syariah mikro berbentuk bank rakyat yang bersentuhan langsung dengan masyarakat/nasabah yang meminjam dananya untuk usaha pertanian. Selanjutnya, dari BPRS tersebut akan dilihat risiko pembiayaan yang ada dan mungkin terjadi. Risiko pembiayaan pada BPRS Amanah Ummah dapat dilihat dari sisi perhimpunan dana dan sisi penyaluran dananya serta dapat dilihat pula risiko pembiayaan khusus yang tidak ada pada bank konvensional, yaitu risiko yang melekat karena adanya karakteristik unik dalam bank syariah, seperti pola bagi hasil. Selain itu, dapat dilihat apa saja faktor-faktor penyebab beberapa produk pembiayaan syariah yang sesuai untuk sektor pertanian tidak direalisasikan oleh BPRS kemudian hal tersebut dianalisis kaitannya terhadap risiko.

Risiko pembiayaan pada BPRS hanya difokuskan kepada hal-hal yang berkaitan secara langsung maupun tidak langsung dengan sektor pertanian kemudian risiko akan diidentifikasi, dihitung serta dipetakan sesuai dengan tingkat risikonya. Setelah dipetakan risiko pembiayaannya, akan dianalisis tindakan mitigasi risiko yang tepat dalam

\footnotetext{
${ }^{2}$ Menurut Abduh M. Khalid dalam http://www.amanahummah.co.id/index.php?option=com_content\&view=article\&id=153\%3Arepu blika\&catid $=42 \% 3$ Arokstories\&Itemid $=29$ [diakses 2012 November 15]
} 
menanggulanginya. Hal ini penting bagi perkembangan pembiayaan syariah agar dapat diketahui kaitan antara risiko pembiayaan syariah dengan sektor pertanian. Bagi pihak BPRS, hal ini penting karena dengan mengetahui risiko pembiayaan untuk sektor pertanian, akan diketahui langkah-langkah apa saja yang harus dilakukan ke depannya sebagai tindak lanjut dalam menangani risiko pembiayaan dan kerugian yang mungkin ditimbulkan. Adapun tujuan dari penelitian ini yaitu sebagai berikut:

1. Mengidentifikasi risiko pembiayaan untuk sektor pertanian dan risiko lainnya pada proses pembiayaan di BPRS Amanah Ummah.

2. Menganalisis pengukuran dan pemetaan risiko pembiayaan untuk sektor pertanian dan risiko lainnya pada proses pembiayaan di BPRS Amanah Ummah.

3. Menghitung potensi kerugian pembiayaan untuk sektor pertanian pada BPRS Amanah Ummah.

4. Menganalisis tindakan mitigasi risiko pembiayaan untuk sektor pertanian dan risiko lainnya pada proses pembiayaan di BPRS Amanah Ummah.

\section{Tinjauan Pustaka}

\subsection{Penelitian Terdahulu}

Terdapat beberapa penelitian yang membahas pembiayaan syariah pada sektor pertanian dan risiko pembiayaan syariah. Penelitian Ashari dan Saptana (2005) memiliki kesamaan dengan penelitian ini dalam hal pembahasan pembiayaan syariah pada sektor pertanian. Skema dan produk pembiayaan syariah memiliki kesesuaian tinggi dengan karakteristik usaha pertanian dan terdapat 7 hal yang menunjukkan prospek positif pembiayaan syariah untuk sektor pertanian. Namun, keterbatasan dalam penelitian yang dilakukan Ashari dan Saptana (2005) yaitu menggunakan perspektif makro (keadaan pembiayaan syariah dan pertanian di Indonesia) sehingga belum tentu sesuai dengan keadaan nyata yang terjadi di lapangan secara mikro, misalnya pada lembaga pembiayaan seperti BPRS yang langsung bersentuhan dengan masyarakat.

Selanjutnya, penelitian Triawan (2008) memiliki kesamaan dengan penelitian ini dalam hal lokasi penelitian, metode perhitungan potensi kerugian pembiayaan, dan analisis tindakan strategi mitigasi risiko. Hasil dari penelitian ini yaitu portofolio pembiayaan syariah yang optimal di BPRS Amanah Ummah adalah $84.76 \%$ pembiayaan murabahah; $6.85 \%$ mudharabah; $1.53 \%$ salam; $0.29 \%$ ijarah; dan $1.00 \%$ qardh dan pengelolaan risiko yang dilakukan BPRS Amanah Ummah adalah analisis pembiayaan dengan prinsip $5 \mathrm{C}$ serta penanganan pembiayaan bermasalah.

\subsection{Enterprise Risk Management (ERM)}

Dalam melakukan penelitian ini, metode yang digunakan adalah Enterprise Risk Management (ERM). ERM adalah seluruh metode dan proses yang digunakan organisasi perusahaan untuk mengelola risiko, baik dalam menghindari kerugian maupun untuk meraih peluang yang menguntungkan, berkaitan dengan pencapaian tujuan organisasi perusahaan (Siahaan 2009: 334). Secara garis besar, ERM meliputi 3 tahap. Pertama, pengidentifikasian keadaan-keadaan yang terjadi berkaitan dengan pencapaian tujuan perusahaan untuk mengoptimalkan risiko kerugian dan meraih risiko peluang yang menguntungkan. Kedua, menilai risiko dengan 2 dimensi, yaitu dimensi kemungkinan terjadinya (probability) dan dimensi dampak terjadinya (impact). Ketiga, menentukan 
strategi yang tepat dalam menghadapi risiko yang bersangkutan. Ringkasnya, ERM membantu sebuah perusahaan untuk dapat mencapai tujuan organisasi dan menghindari risiko-risiko yang terjadi dalam perjalanan menuju tujuan tersebut.

\subsubsection{Identifikasi BPRS Amanah Ummah}

1. ERM 1: Internal Environment.

Identifikasi lingkungan internal pada BPRS Amanah Ummah didapat dari hasil observasi dan wawancara dengan direktur BPRS Amanah Ummah.

2. ERM 2: Objective Setting.

Identifikasi objective setting diperoleh dari jabaran visi dan misi serta sasaran perusahaan yang telah ditetapkan oleh BPRS Amanah Ummah.

\subsubsection{Identifikasi Risiko}

ERM 3: Event Identification. Hal yang dilakukan adalah mengidentifikasi risiko yang mungkin terjadi dalam suatu aktivitas pembiayaan dengan cara mendaftar seluruh peristiwa risiko yang mungkin terjadi. Teknik-teknik yang dapat digunakan antara lain brainstorming, wawancara dengan responden yang telah dipilih, pengamatan secara langsung, serta pengumpulan data statistik dan data historis dari pihak BPRS Amanah Ummah.

\subsubsection{Pengukuran dan Pemetaan Risiko}

ERM 4: Risk Assessment. Godfrey (1996), risiko dapat diukur dalam 2 perspektif, yaitu berdasarkan probability (peluang atau kemungkinan terjadi) dan impact (dampak jika terjadi risiko). Penilaian mengenai kemungkinan terjadinya risiko dapat dilihat pada Tabel 3.

\section{Tabel 3 Probabilitas risiko ${ }^{a}$}

\begin{tabular}{lll}
\hline Angka & \multicolumn{1}{c}{ Skala probabilitas } & \multicolumn{1}{c}{ Keterangan } \\
\hline 1 & Sangat rendah (improbable) & hampir tidak mungkin terjadi \\
2 & Rendah (remote) & kadang terjadi \\
3 & Sedang (occasional) & mungkin terjadi \\
4 & Tinggi (probable) & sangat mungkin terjadi \\
5 & Sangat tinggi (frequent) & hampir pasti terjadi \\
\hline a Sumber: & Godfrey $(1996)$ &
\end{tabular}

a Sumber: Godfrey (1996)

Tabel 3 menunjukkan angka yang berarti nilai skala. Keterangan menunjukkan penjelasan kualitatif mengenai probabilitas risiko. Selanjutnya, penilaian mengenai dampak terjadinya risiko dapat dilihat pada Tabel 4.

Tabel 4 Penilaian dampak terjadinya risiko Tabel 4 Dampak risiko ${ }^{a}$

\begin{tabular}{|c|c|c|}
\hline Angka & Skala dampak & Keterangan \\
\hline 1 & $\begin{array}{l}\text { Sangat rendah } \\
\text { (negligible) }\end{array}$ & Tidak menimbulkan masalah \\
\hline 2 & $\begin{array}{l}\text { Rendah } \\
\text { (marginal) }\end{array}$ & Menimbulkan masalah kecil yang dapat diatasi dengan pengelolaan rutin \\
\hline 3 & $\begin{array}{l}\text { Sedang } \\
\text { (serious) }\end{array}$ & Mencegah perusahaan memenuhi tujuannya untuk periode tertentu saja \\
\hline 4 & Tinggi (critical) & $\begin{array}{l}\text { Mengakibatkan perusahaan tidak dapat mencapai sebagian tujuan jangka } \\
\text { panjang, mengganggu likuiditas perusahaan }\end{array}$ \\
\hline 5 & $\begin{array}{l}\text { Sangat tinggi } \\
\text { (catastrophic) }\end{array}$ & $\begin{array}{l}\text { Mengakibatkan perusahaan tidak dapat mencapai seluruh tujuan jangka } \\
\text { panjang, menyebabkan kebangkrutan, kematian, hukuman pidana }\end{array}$ \\
\hline
\end{tabular}


aSumber: Godfrey (1996)

Tabel 4 menunjukkan angka yang berarti nilai skala. Keterangan menunjukkan penjelasan kualitatif mengenai dampak terjadinya risiko. Evaluasi dampak risiko seringkali cukup sulit untuk diukur karena berkaitan dengan berbagai macam aspek dan pertimbangan.

Pengukuran risiko juga dapat menggunakan metode aproksimasi. Kountur (2008) menjelaskan bahwa metode aproksimasi adalah cara untuk mengetahui probabilitas dan dampak risiko dengan cara menanyakan perkiraan probabilitas dan dampak dari suatu risiko berdasarkan opini para ahli. Opini para ahli merupakan salah satu cara pengumpulan informasi dimana seseorang yang dianggap ahli diwawancarai untuk mendapatkan informasi tentang berapa besar kemungkinan/probabilitas dan berapa besar dampak yang terjadi dari suatu risiko. Risiko-risiko yang telah diidentifikasi sebelumnya ditunjukkan kepada para ahli dan diminta pendapatnya untuk memberikan perkiraan. Penggunaan metode aproksimasi menjadikan pengukuran risiko tetap dapat dilakukan jika data statistik, informasi historis atau data kuantitatif lainnya tidak tersedia.

Godfrey (1996) menjelaskan bahwa nilai risiko merupakan perkalian dari probabilitas dan dampak. Untuk mengukur risiko dapat digunakan rumus:

Keterangan:

$$
\mathrm{R}=\mathrm{P} \times \mathrm{I}
$$

$\mathrm{R}=$ Tingkat risiko

$\mathrm{P}=$ Kemungkinan risiko terjadi

$\mathrm{I}=$ Dampak bila risiko benar-benar terjadi

Selanjutnya, hasil dari pengukuran risiko dapat dikelompokkan ke dalam pemetaan. Pemetaan ini dapat menunjukkan nilai pada masing-masing risiko sesuai dengan tingkatan risikonya. Pemetaan tingkat risiko dapat dijelaskan oleh Tabel 5.

Tabel 5 Pemetaan risiko ${ }^{a}$

\begin{tabular}{|c|c|c|c|c|c|c|c|}
\hline & \multicolumn{5}{|c|}{ Impact } \\
\hline & & & Catastrophic & Critical & Serious & Marginal & Negligible \\
\hline & & & 5 & 4 & 3 & 2 & 1 \\
\hline \multirow{5}{*}{$\begin{array}{l}2 \\
: \\
0 \\
0 \\
0 \\
0 \\
2\end{array}$} & Frequent & 5 & 25 & 20 & 15 & 10 & 5 \\
\hline & Probable & 4 & 20 & 16 & 12 & 8 & 4 \\
\hline & Occasional & 3 & 15 & 12 & 9 & 6 & 3 \\
\hline & Remote & 2 & 10 & 8 & 6 & 4 & 2 \\
\hline & Improbable & 1 & 5 & 4 & 3 & 2 & 1 \\
\hline
\end{tabular}

a Sumber: Godfrey (1996)

Tabel 5 menunjukkan bahwa pemetaan risiko dapat dilihat dari perkalian nilai kemungkinan terjadinya risiko (probability) dan dampak jika risiko terjadi (impact). Setelah itu, Godfrey (1996) membagi 4 tingkat penerimaan risiko berdasarkan kecenderungan peluang terjadinya risiko dan dampaknya, seperti yang ditunjukkan pada Tabel 6. Tingkat penerimaan risiko ini dapat menjadi bahan pertimbangan dalam mengambil respon tindakan mitigasi risiko. 
Tabel 6 Tingkat penerimaan risiko ${ }^{a}$

\begin{tabular}{|c|c|c|c|c|c|c|}
\hline & \multicolumn{5}{|c|}{ Impact } \\
\hline & & $\begin{array}{c}\text { Catastrophic } \\
5\end{array}$ & $\begin{array}{c}\text { Critical } \\
4\end{array}$ & $\begin{array}{c}\text { Serious } \\
3\end{array}$ & $\begin{array}{l}\text { Marginal } \\
2\end{array}$ & $\begin{array}{c}\text { Negligible } \\
1\end{array}$ \\
\hline \multirow{2}{*}{\multicolumn{2}{|c|}{ Frequent }} & $5 \quad 25$ & 20 & 15 & 10 & 5 \\
\hline & & unacceptable & unacceptable & unacceptable & undesirable & undesirable \\
\hline \multirow{4}{*}{$\stackrel{\Xi}{*}$} & \multirow{2}{*}{ Probable } & $4 \quad 20$ & 16 & 12 & 8 & 4 \\
\hline & & unacceptable & unacceptable & undesirable & undesirable & acceptable \\
\hline & \multirow{2}{*}{ Occasional 3} & $3 \quad 15$ & 12 & 9 & 6 & 3 \\
\hline & & unacceptable & undesirable & undesirable & undesirable & acceptable \\
\hline \multirow[t]{4}{*}{$=$} & Domoto & $2 \quad 10$ & 8 & 6 & 4 & 2 \\
\hline & Remote & undesirable & undesirable & undesirable & acceptable & negligible \\
\hline & 1 & 15 & 4 & 3 & 2 & 1 \\
\hline & & undesirable & acceptable & acceptable & negligible & negligible \\
\hline
\end{tabular}

a Sumber: Godfrey (1996)

Tabel 6 menunjukkan 4 tingkatan penerimaan risiko. Keempat tingkatan tersebut yaitu unaccpetable, undesirable, acceptable, dan negligible. Tingkatan pertama adalah unacceptable. Unacceptable adalah risiko tinggi karena memberikan pengaruh signifikan yang merugikan perusahaan dan memiliki efek domino dalam jangka panjang sehingga harus mendapat prioritas utama. Respon tindakan utama dalam mengendalikan risiko ini yaitu dihindari atau ditransfer.

Tingkatan kedua adalah undesirable. Undesirable adalah risiko yang harus diwaspadai karena sudah melewati batas toleransi perusahaan dan berpengaruh signifikan terhadap perusahaan. Respon tindakan dalam mengendalikan risiko ini yaitu dihindari dan dikurangi.

Tingkatan ketiga adalah acceptable. Acceptable adalah risiko yang dapat diterima. Risiko ini memberikan dampak bagi perusahaan tetapi masih dalam batas toleransi sehingga masih dapat diatasi. Respon tindakan dalam mengendalikan risiko ini yaitu tidak mengambil tindakan apapun (menerima) atau mengurangi kemungkinan terjadinya risiko, jika memungkinkan.

Tingkatan keempat adalah negligible. Negligible adalah risiko yang jarang terjadi dan bila terjadi memiliki dampak yang relatif kecil. Efek dari risiko ini dapat dikurangi, namun biayanya dapat saja melebihi dampak risiko yang ditimbulkan. Pada kasus ini, mungkin lebih baik untuk menerima efek dari risiko tersebut.

\subsubsection{Tindakan Mitigasi Risiko}

1. ERM 5: Risk Response.

Respon terhadap peristiwa risiko dianalisis dari hasil pemetaan risiko, studi literatur, dan diskusi dengan pihak BPRS Amanah Ummah. Risk response dianalisis secara deskriptif dan dibagi ke dalam respon menerima (accept), mengurangi (reduce), berbagi (transfer), menghindari (avoid), dan menghilangkan risiko (remove). Tindakan mitigasi risiko yang sudah dijalankan oleh BPRS Amanah Ummah juga akan diidentifikasi dan dianalisis secara deskriptif.

2. ERM 6: Control Activities. 
Kendali terhadap risiko akan dijelaskan melalui pendekatan analisis deskriptif. Penjelasan mengenai kendali aktivitas juga akan melengkapi uraian dari tindakan mitigasi risiko sebelumnya (risk response).

3. ERM 7: Information and Communication.

Tindakan mitigasi risiko yang berkaitan dengan alur penyampaian informasi dan komunikasi dianalisis dengan pendekatan deskriptif dan dibagi berdasarkan pihak-pihak yang terkait dalam keseluruhan proses pembiayaan dan operasional. Pihak-pihak terkait yaitu pihak internal bank, nasabah bank, para pemegang saham, pihak regulator dan pengawas, serta pihak ekstenal lainnya.

4. ERM 8: Monitoring.

Tindakan pengendalian sebagai salah satu komponen mitigasi risiko dianalisis secara deskriptif dan perolehan informasi didapat dari data internal BPRS Amanah Ummah, diskusi dengan pihak BPRS Amanah Ummah, dan observasi langsung.

\section{Metode}

Tahap pertama yang dilakukan dalam mengidentifikasi risiko, ditinjau dari sisi perhimpunan dan penyaluran dananya adalah mengidentifikasi produk dan proses pembiayaan yang terdapat pada BPRS. Tahapan kedua yaitu menganalisis proses penyaluran dana dan aspek risiko pembiayaan maupun operasionalnya. Tahapan ketiga yaitu menganalisis risiko dalam penyaluran dana untuk sektor pertanian di BPRS Amanah Ummah yang didominasi oleh pembiayaan murabahah serta risiko lainnya yang terkait.

Pada pengukuran risiko pembiayaan, dihitung juga potensi kerugian pembiayaan pada sektor pertanian dengan menggunakan metode creditrisk+. Penilaian keseluruhan risiko dari kegiatan pembiayaan ini kemudian akan diidentifikasi, diukur, dipetakan, dan dianalisis tindakan mitigasi risikonya melalui sebuah kerangka manajemen risiko Enterprise Risk Management (ERM). Penerapan manajemen risiko dengan metode ERM harus dilakukan sesuai dengan 8 komponen ERM agar dapat terlaksana secara efektif. Delapan komponen ERM yaitu internal environment, objective setting, event identification, risk assessment, risk response, control activities, information and communication, dan monitoring. Keseluruhan analisis risiko pembiayaan yang dilakukan dalam penelitian ini nantinya dapat dijadikan bahan evaluasi pembiayaan syariah, khususnya untuk sektor pertanian dalam tinjauan manajemen risiko.

\subsection{Metode Pengumpulan Data}

Data yang digunakan dalam penelitian ini berupa data primer dan data sekunder. Data primer diperoleh melalui penyebaran kuesioner dan wawancara langsung dengan pihak BPRS Amanah Ummah serta wawancara dengan nasabah/pelaku usaha pada sektor pertanian. Data sekunder diperoleh dari arsip, dokumen, dan laporan tahunan BPRS Amanah Ummah. Metode pengumpulan data yang digunakan yaitu metode observasi, penelusuran literatur, penyebaran kuesioner, wawancara, dan diskusi mendalam. Informasi atau keterangan diperoleh melalui data primer langsung dari pihak BPRS Amanah Ummah.

\subsection{Metode Pengambilan Sampel}

Metode pengambilan sampel dalam penelitian ini menggunakan metode purposive sampling (pengambilan sampel dengan sengaja). Responden telah dipilih dengan 
pertimbangan bahwa responden tersebut memiliki pengetahuan, keahlian, dan kompetensi dalam bidang yang dikaji. Responden terpilih dari pihak BPRS Amanah Ummah meliputi direktur, audit internal, kepala bidang operasional, kepala bidang marketing, dan bagianbagian di bawahnya (account officer, legal officer, administrasi pembiayaan (ADMP)).

\subsection{Metode Pengolahan dan Analisis Data}

Secara garis besar, pengolahan dan analisis data dalam penelitian ini dapat dilihat pada Tabel 7.

Tabel 7 Matriks metode pengolahan dan analisis data

\begin{tabular}{|c|c|c|c|}
\hline No. & Tujuan & Sumber Data & $\begin{array}{c}\text { Analisis dan } \\
\text { Pengolahan Data }\end{array}$ \\
\hline 1. & $\begin{array}{l}\text { Mengidentifikasi risiko pembiayaan untuk } \\
\text { sektor pertanian dan risiko lainnya pada } \\
\text { proses pembiayaan di BPRS Amanah } \\
\text { Ummah }\end{array}$ & $\begin{array}{lr}\text { Wawancara } & \text { dengan } \\
\text { pihak BPRS Amanah } \\
\text { Ummah, studi literatur, } \\
\text { internet }\end{array}$ & $\begin{array}{l}\text { Metode ERM dan } \\
\text { analisis deskriptif }\end{array}$ \\
\hline 2. & $\begin{array}{l}\text { Menganalisis pengukuran dan pemetaan } \\
\text { risiko pembiayaan untuk sektor pertanian } \\
\text { dan risiko lainnya pada proses pembiayaan } \\
\text { di BPRS Amanah Ummah }\end{array}$ & $\begin{array}{l}\text { Wawancara, diskusi } \\
\text { mendalam dengan pihak } \\
\text { BPRS Amanah Ummah }\end{array}$ & $\begin{array}{l}\text { Metode ERM, metode } \\
\text { aproksimasi }\end{array}$ \\
\hline 3. & $\begin{array}{l}\text { Menghitung potensi kerugian pembiayaan } \\
\text { untuk sektor pertanian pada BPRS Amanah } \\
\text { Ummah }\end{array}$ & $\begin{array}{l}\text { Data internal BPRS } \\
\text { Amanah Ummah }\end{array}$ & Metode creditrisk+ \\
\hline 4. & $\begin{array}{l}\text { Menganalisis tindakan mitigasi risiko } \\
\text { pembiayaan untuk sektor pertanian dan } \\
\text { risiko lainnya pada proses pembiayaan di } \\
\text { BPRS Amanah Ummah }\end{array}$ & \begin{tabular}{lrr} 
Diskusi & \multicolumn{2}{r}{ mendalam } \\
dengan & pihak BPRS \\
Amanah & Ummah dan \\
para ahli & & \\
\end{tabular} & $\begin{array}{l}\text { Metode ERM dan } \\
\text { analisis deskriptif }\end{array}$ \\
\hline
\end{tabular}

a Sumber: Diolah oleh penulis (2013)

Metode penelitian kualitatif dan kuantitatif digunakan pada penelitian ini. Metode penelitian kualitatif digunakan untuk menganalisis risiko pembiayaan pada sektor pertanian di BPRS Amanah Ummah. Alat analisis yang dipakai adalah metode Enterprise Risk Management (ERM) dan analisis deskriptif.

Metode penelitian kuantitatif digunakan untuk mengukur risiko pembiayaan dan mengukur potensi kerugian yang mungkin terjadi pada pembiayaan sektor pertanian di BPRS Amanah Ummah. Pengukuran potensi kerugian dihitung dengan metode creditrisk+. Alat yang digunakan dalam pengolahan data untuk menghitung potensi kerugian adalah Minitab 14 dan Microsoft Excel.

Tahapan penelitian yang digunakan dalam menganalisis risiko pembiayaan untuk sektor pertanian di BPRS Amanah Ummah terdiri dari 8 komponen Enterprise Risk Management (ERM) yang sudah dijelaskan pada Bab Tinjauan Pustaka. Delapan tahapan komponen ERM tersebut dapat dibagi ke dalam proses identifikasi BPRS Amanah Ummah (2 komponen), identifikasi risiko (1 komponen), pengukuran dan pemetaan risiko (1 komponen), serta tindakan mitigasi risiko (4 komponen). Selain tahapan komponen ERM, terdapat pula perhitungan potensi kerugian pembiayaan pada sektor pertanian di BPRS Amanah Ummah menggunakan metode creditrisk+ (Lihat Lampiran).

\section{Hasil dan Pembahasan}

\subsection{Identifikasi BPRS Amanah Ummah}

ERM 1: Internal Environment 
BPRS Amanah Ummah merupakan organisasi berbentuk perseroan terbatas yang sudah berdiri selama 20 tahun sejak tahun 1992. BPRS Amanah Ummah terus berusaha menjalankan tata kelola perusahaan yang baik dengan melaksanakan kegiatan manajemen risiko untuk mengidentifikasi, memantau, dan mengendalikan risiko yang mungkin timbul dari kegiatan bank. Manajemen risiko yang efektif dan efisien juga diimplementasikan oleh BPRS untuk dapat mencapai tujuan perusahaan dengan tetap menjunjung tinggi asas prudential banking (kehati-hatian) dan sharia compliance (prinsip syariah). Selain itu, sesuai dengan prinsip good corporate governance (GCG), BPRS Amanah Ummah juga membentuk tim audit internal.

BPRS Amanah Ummah memiliki motto yaitu "Meraih Laba, Menepis Riba, Mengundang Berkah". Ketiga slogan motto tersebut merupakan nilai-nilai yang ditanamkan kepada seluruh jajaran direksi dan karyawan dalam mengerjakan tugasnya. Selain motto tersebut, terdapat pula budaya perusahaan yang ditanamkan kepada seluruh direksi dan karyawan yaitu "Pelayanan Cepat, Amanah, dan Ramah". Motto dan budaya perusahaan itulah yang kemudian diinternalisasikan kepada seluruh direksi maupun karyawan dan menjadi nilai-nilai kepercayaan yang selama ini dianut dalam mengerjakan segala tugasnya.

Dalam hal permodalan dan keuangan, tercatat pada tahun 2012 BPRS Amanah Ummah memiliki rasio kecukupan modal (CAR) sebesar $14.17 \%$, pendapatan dari seluruh produk pembiayaan sebesar Rp13 625603 000, dan laba bersih sebesar Rp1 568171 000. Selain itu, BPRS Amanah Ummah memiliki reputasi yang cukup baik di masyarakat dan beroperasi di pusat perdagangan (Pasar Leuwiliang) sehingga dekat dengan masyarakat. Beberapa hal tersebut mendukung BPRS Amanah Ummah untuk dapat tumbuh dan lebih berkembang menjadi bank yang lebih besar dan bersaing dengan perbankan syariah maupun konvensional lainnya.

\section{ERM 2: Objective Setting}

Visi yang ditetapkan BPRS Amanah Ummah adalah menjadi BPRS pilihan umat, amanah dan profesional sedangkan misinya yaitu membangun kualitas kehidupan umat melalui perbankan syariah. Selain visi dan misi tersebut, BPRS Amanah Ummah juga memiliki sasaran yang dituju dalam rangka mematuhi pelaksanaan tata kelola perusahaan yang baik. Sasaran-sasaran tersebut yaitu menumbuhkan budaya patuh terhadap peraturan, sadar risiko dalam rangka pelaksanaan prudential banking dan sharia compliance, serta menjaga pertumbuhan bisnis bank.

Adapun arahan strategi dari Bank Indonesia yaitu perbankan syariah difokuskan untuk mendorong pemerataan ekonomi masyarakat dengan penjelasan sebagai berikut:

1. Mengarahkan pembiayaan perbankan syariah pada sektor ekonomi produktif dan masyarakat yang lebih luas.

2. Mengembangkan produk yang lebih memenuhi kebutuhan masyarakat dan sektor produktif.

3. Melaksanakan transisi pengawasan yang tetap menjaga kesinambungan pengembangan perbankan syariah.

4. Meningkatkan edukasi dan komunikasi produk perbankan syariah.

\subsection{Identifikasi Risiko}

ERM 3: Event Identification 
Pengidentifikasian risiko yang terjadi pada BPRS Amanah Ummah dapat dilakukan melalui pengamatan di lapangan dan wawancara dengan pihak internal bank. Secara garis besar, risiko pada BPRS Amanah Ummah yang diteliti dalam penelitian ini terbagi menjadi 2 kelompok yaitu risiko internal dan eksternal. Risiko internal terbagi menjadi risiko pembiayaan dan risiko operasional sedangkan risiko eksternal mencakup risiko secara umum yang dipengaruhi oleh pihak luar bank.

Identifikasi pertama yaitu risiko pembiayaan. Risiko pembiayaan merupakan risiko yang disebabkan oleh adanya kegagalan counterparty (pihak ketiga) dalam memenuhi kewajibannya (Karim 2009). Risiko utama dalam pembiayaan adalah timbulnya pembiayaan bermasalah dan macet. Menurut pihak BPRS Amanah Ummah, pembiayaan bermasalah adalah suatu kinerja pembiayaan yang menunjukkan kondisi tidak berjalan sesuai harapan atau adanya isyarat/tanda nasabah tidak dapat membayar kewajiban sesuai jadwal, atau syarat-syarat lain yang telah ditetapkan. Di sisi lain, pembiayaan macet adalah kondisi pembiayaan bermasalah tidak menunjukkan tanda-tanda dapat disehatkan, cenderung tidak dapat ditagih lagi, dan tidak dapat dilakukan tindakan penyelamatan kembali.

Pembiayaan bermasalah dan macet dapat menimbulkan beberapa kerugian untuk bank, seperti kehilangan perolehan pendapatan marjin, kehilangan bagi hasil dan saldo pokok pembiayaan, turunnya rentabilitas usaha bank, dan kehilangan kesempatan pengembangan usaha. Kerugian lainnya yaitu dapat menimbulkan reputasi negatif terhadap bank, timbulnya penambahan biaya untuk pengacara dan kolektor, kerugian personalia seperti waktu, tenaga dan moral, serta penurunan solvabilitas/permodalan bank. Potensi-potensi risiko pada tahapan proses pembiayaan di BPRS Amanah Ummah dapat dijelaskan sebagai berikut:

\section{Pengajuan Pembiayaan}

Risiko yang mungkin terjadi dalam tahap ini adalah adanya pemalsuan data dan ketidakjujuran dari nasabah saat mengajukan pembiayaan dan melengkapi segala persyaratannya. Risiko lainnya yaitu kurangnya pengetahuan nasabah yang akan meminjam dana akan produk dan prinsip pembiayaan syariah sehingga berpotensi untuk menimbulkan kekeliruan dalam memilih pembiayaan yang dibutuhkan.

2. Analisis Pembiayaan

Pada tahap ini, risiko yang terkandung yaitu pihak bank gagal/kurang teliti dalam menganalisis aspek 5C (character, capability, capital, condition, dan collateral) dari nasabah, adanya pemalsuan jaminan dari nasabah, rendahnya nilai jual kembali jaminan yang diberikan nasabah, adanya tuntutan hukum pihak lain atas jaminan dari nasabah, dan adanya sertifikat ganda (misalnya pada sertifikat tanah).

3. Penilaian Dokumen

Tidak ditemukan potensi risiko dalam proses ini karena analisis dan pembuatan proposal pengajuan pembiayaan dilakukan secara objektif oleh AO yang sudah melakukan survei langsung ke lapangan.

4. Pengajuan ke Komite Kebijakan Pembiayaan.

Tidak ditemukan potensi risiko dalam proses ini karena persetujuan terhadap pengajuan pembiayaan telah diputuskan oleh pihak yang ahli dalam menganalisis pembiayaan dari bank.

5. Persetujuan dan Pengikatan 
Pada tahap ini, ditemukan potensi risiko yaitu adanya kekeliruan dalam penetapan akad pembiayaan yang nantinya dapat menimbulkan ketidakcocokan antara kebutuhan pembiayaan usaha dengan produk pembiayaan itu sendiri.

6. Pencairan

Pada tahap ini, risiko yang terkandung adalah keterlambatan pihak bank dalam memproses pengajuan pembiayaan nasabah dan adanya kesalahan prosedur dalam melakukan serangkaian proses pembiayaan tersebut.

7. Pembinaan dan Pengawasan

Risiko yang mungkin terjadi pada tahap ini adalah kurangnya tinjauan lanjutan dari pihak bank kepada nasabah yang diberikan pembiayaan sehingga dapat menimbulkan hilangnya kontrol dan terlambatnya pembayaran angsuran. Risiko lainnya yaitu adanya keterlambatan pihak bank dalam menangani pembiayaan yang bermasalah. Hal ini sangatlah vital karena pembiayaan bermasalah dapat menghambat perputaran keuangan dan performa bank sehingga membutuhkan penanganan khusus.

8. Pelunasan

Pada tahap terakhir ini, tidak semua nasabah selesai membayar seluruh angsuran tepat pada waktunya. Terkadang ada nasabah yang terlambat dalam mengembalikan pembiayaan atau bahkan mengalami default/gagal bayar. Risiko gagal bayar ini dapat terjadi karena beberapa hal, seperti karakter buruk dan moral hazard nasabah, usaha nasabah mengalami kebangkrutan atau usaha nasabah mengalami gagal panen, bencana alam, dan force majeure.

Kegiatan pembiayaan untuk sektor pertanian memiliki prosedur yang sama dengan kegiatan pembiayaan untuk sektor lain. Oleh karena itu, risiko-risiko yang telah dijelaskan sebelumnya dapat digolongkan ke dalam risiko pembiayaan untuk sektor pertanian. Beberapa hal yang membedakannya adalah sumber risiko dari terjadinya risiko pembiayaan. Pada sektor pertanian, sumber risiko dari gagal bayar/default biasanya berasal dari terjadinya gagal panen, fluktuasi cuaca, bencana alam, kegagalan produksi, dan sumber-sumber lain yang berkaitan langsung dengan karakteristik usaha pertanian nasabah. Untuk keunikan risiko pembiayaan syariah itu sendiri, terletak pada penerapan prinsip syariah serta spesifikasi kapabilitas sumber daya manusia yang tidak ada dalam praktik perbankan konvensional. Namun, pada kasus ini, tidak dibahas secara mendalam risiko pembiayaan yang terdapat pada produk bagi hasil, seperti mudharabah dan musyarakah karena BPRS Amanah Ummah belum menyalurkan pembiayaan dengan produk-produk tersebut untuk sektor pertanian.

Identifikasi kedua yaitu risiko operasional. Risiko operasional adalah risiko yang disebabkan oleh sumber daya manusia, kegagalan sistem, serta kegagalan sarana dan infrastruktur.

1. Sumber Daya Manusia (SDM).

Risiko SDM dapat ditimbulkan dari tidak berfungsinya fungsi internal dan human error. Tidak berfungsinya fungsi internal yang terjadi pada BPRS Amanah Ummah yaitu seperti adanya keterlambatan dalam penyebaran informasi dari pimpinan kepada karyawan atau bagian di bawahnya, adanya persepsi negatif dari masyarakat terhadap bank, dan perhitungan pembentukan penyisihan aktiva produktif (PPAP) yang tidak dilakukan secara rutin. Selain itu, terdapat human error yang dapat terjadi pada tiap bagian baik disengaja maupun tidak disengaja. Human error dapat disebabkan oleh beberapa hal seperti ketidakmampuan sumber daya manusia dan kelelahan. Pada BPRS Amanah Ummah, risiko yang dapat ditimbulkan karena human error adalah kurangnya pengetahuan SDM bank mengenai prinsip dan praktik pembiayaan syariah, adanya kesalahan dalam pencatatan transaksi/posting, adanya tindakan moral hazard (korupsi, kolusi, pemalsuan), serta hilangnya berkas 
dan arsip. Faktor kurangnya kemampuan komunikasi dan budaya kerja yang kurang sesuai dengan SOP bank juga dapat menjadi risiko.

2. Sistem.

Risiko yang terkandung dalam kegagalan sistem pada BPRS Amanah Ummah adalah sistem teknologi informasi dan jaringan bank mengalami offline atau error.

3. Sarana.

Risiko yang mungkin terjadi yaitu kegagalan sarana seperti komunikasi, listrik, dan air. Terjadinya hal tersebut di luar perkiraan bank dan dapat menghambat kegiatan operasional bank. Risiko lainnya yaitu rusaknya barang yang disewakan karena pemakaian di luar normal atau tidak sesuai prosedur (misalnya pada produk ijarah).

Identifikasi ketiga yaitu risiko eksternal. Dari beberapa risiko eksternal yang mungkin terjadi, terdapat 2 risiko yang dapat terjadi pada BPRS Amanah Ummah. Risiko tersebut yaitu terjadinya bencana alam seperti gempa bumi atau banjir dan adanya kebijakan dari Bank Indonesia yang kurang menguntungkan pihak BPRS. Ringkasan mengenai identifikasi risiko yang telah diuraikan beserta kemungkinan kejadian risiko dan dampak terjadinya risiko dapat dilihat pada Tabel 8 .

Tabel 8 Identifikasi risiko ${ }^{a}$

\begin{tabular}{|c|c|c|c|c|}
\hline $\begin{array}{l}\text { Kelompok } \\
\text { risiko }\end{array}$ & $\begin{array}{l}\text { Nomor } \\
\text { risiko }\end{array}$ & Identifikasi risiko & $\begin{array}{l}\text { Kejadian } \\
\text { risiko }^{\text {b }}\end{array}$ & Dampak terjadinya risiko \\
\hline $\begin{array}{l}\text { A. Risiko } \\
\text { Pembiayaan }\end{array}$ & 1 & $\begin{array}{l}\text { Adanya pemalsuan data dan } \\
\text { ketidakjujuran dari nasabah }\end{array}$ & $\begin{array}{c}11-20 \\
\text { kali }\end{array}$ & $\begin{array}{l}\text { Tindakan pemalsuan dan } \\
\text { batalnya proses } \\
\text { penyaluran pembiayaan }\end{array}$ \\
\hline $\begin{array}{l}\text { Pengajuan } \\
\text { Pembiayaan }\end{array}$ & 2 & $\begin{array}{l}\text { Kurangnya pengetahuan } \\
\text { nasabah pembiayaan akan } \\
\text { produk dan prinsip } \\
\text { pembiayaan syariah }\end{array}$ & $\begin{array}{c}21-50 \\
\text { kali }\end{array}$ & $\begin{array}{l}\text { Kesalahan pengajuan } \\
\text { produk pembiayaan dan } \\
\text { takut dalam mengakses } \\
\text { pembiayaan }\end{array}$ \\
\hline \multirow[t]{5}{*}{$\begin{array}{l}\text { Analisis } \\
\text { Pembiayaan }\end{array}$} & 3 & $\begin{array}{l}\text { Pihak bank gagal/kurang } \\
\text { teliti dalam menganalisis } \\
\text { aspek } 5 \mathrm{C}^{\mathrm{c}} \text { dari nasabah }\end{array}$ & $\begin{array}{c}11-20 \\
\text { kali }\end{array}$ & $\begin{array}{l}\text { Kesalahan pemberian } \\
\text { plafon pembiayaan } \\
\text { kepada nasabah }\end{array}$ \\
\hline & 4 & $\begin{array}{l}\text { Pemalsuan jaminan dari } \\
\text { nasabah }\end{array}$ & $\begin{array}{l}\text { Tidak } \\
\text { pernah }\end{array}$ & $\begin{array}{l}\text { Tidak menimbulkan } \\
\text { masalah berarti }\end{array}$ \\
\hline & 5 & $\begin{array}{l}\text { Rendahnya nilai jual kembali } \\
\text { jaminan }\end{array}$ & 5 kali & $\begin{array}{l}\text { Nilai jual jaminan tidak } \\
\text { setara dengan jumlah } \\
\text { pembiayaan bermasalah }\end{array}$ \\
\hline & 6 & $\begin{array}{l}\text { Adanya tuntutan hukum } \\
\text { pihak lain atas jaminan dari } \\
\text { nasabah }\end{array}$ & $\begin{array}{l}\text { Tidak } \\
\text { pernah }\end{array}$ & $\begin{array}{l}\text { Tidak menimbulkan } \\
\text { masalah berarti }\end{array}$ \\
\hline & 7 & $\begin{array}{l}\text { Adanya sertifikat ganda } \\
\text { (pada jaminan seperti tanah) }\end{array}$ & $<5$ kali & $\begin{array}{l}\text { Tidak menimbulkan } \\
\text { masalah berarti }\end{array}$ \\
\hline \multirow{3}{*}{$\begin{array}{l}\text { Persetujuan } \\
\text { dan } \\
\text { Pengikatan } \\
\text { Akad } \\
\text { Pencairan }\end{array}$} & 8 & $\begin{array}{l}\text { Adanya kekeliruan dalam } \\
\text { penetapan akad }\end{array}$ & 5-10 kali & $\begin{array}{l}\text { Ketidaksesuaian dengan } \\
\text { kebutuhan usaha nasabah } \\
\text { dan tidak sahnya akad } \\
\text { yang ditetapkan }\end{array}$ \\
\hline & 9 & $\begin{array}{l}\text { Keterlambatan pihak bank } \\
\text { dalam memproses pengajuan } \\
\text { pembiayaan }\end{array}$ & 5-10 kali & $\begin{array}{l}\text { Menimbulkan reputasi } \\
\text { negatif bagi bank dan } \\
\text { turunnya kredibilitas } \\
\text { bank }\end{array}$ \\
\hline & 10 & $\begin{array}{l}\text { Kesalahan prosedur dalam } \\
\text { melakukan proses }\end{array}$ & 5-10 kali & $\begin{array}{l}\text { Ketidaksesuaian dengan } \\
\text { prinsip syariah dan }\end{array}$ \\
\hline
\end{tabular}




\begin{tabular}{|c|c|c|c|c|}
\hline \multirow{3}{*}{$\begin{array}{l}\text { Pembinaan } \\
\text { dan } \\
\text { Pengawasan }\end{array}$} & \multicolumn{2}{|r|}{ pembiayaan } & \multicolumn{2}{|r|}{ taksiran pembiayaan } \\
\hline & 11 & $\begin{array}{l}\text { Kurangnya follow-up dari } \\
\text { pihak bank kepada nasabah }\end{array}$ & $5-10$ kali & $\begin{array}{l}\text { Terhambatnya proses } \\
\text { pembiayaan }\end{array}$ \\
\hline & 12 & $\begin{array}{l}\text { Terlambatnya pihak bank } \\
\text { dalam menangani } \\
\text { pembiayaan yang } \\
\text { bermasalah }\end{array}$ & $5-10$ kali & $\begin{array}{l}\text { Terhambatnya proses } \\
\text { pembiayaan }\end{array}$ \\
\hline \multirow[t]{4}{*}{ Pelunasan } & 13 & $\begin{array}{l}\text { Nasabah mengalami default } \\
\text { (gagal bayar) karena karakter } \\
\text { buruk dan bahaya moral } \\
\text { (moral hazard) nasabah }\end{array}$ & $\begin{array}{c}21-50 \\
\text { kali }\end{array}$ & $\begin{array}{l}\text { Terganggunya likuiditas } \\
\text { perusahaan }\end{array}$ \\
\hline & 14 & $\begin{array}{l}\text { Nasabah mengalami default } \\
\text { (gagal bayar) karena } \\
\text { usahanya mengalami } \\
\text { kebangkrutan }\end{array}$ & $\begin{array}{c}11-20 \\
\text { kali }\end{array}$ & $\begin{array}{l}\text { Terganggunya likuiditas } \\
\text { perusahaan }\end{array}$ \\
\hline & 15 & $\begin{array}{l}\text { Nasabah mengalami default } \\
\text { (gagal bayar) karena } \\
\text { usahanya mengalami } \\
\text { kegagalan panen/terkena } \\
\text { bencana alam }\end{array}$ & $\begin{array}{c}11-20 \\
\text { kali }\end{array}$ & $\begin{array}{l}\text { Terganggunya likuiditas } \\
\text { perusahaan }\end{array}$ \\
\hline & 16 & $\begin{array}{l}\text { Nasabah terlambat dalam } \\
\text { mengembalikan pembiayaan } \\
\text { yang diberikan oleh bank }\end{array}$ & $\begin{array}{c}11-20 \\
\text { kali }\end{array}$ & $\begin{array}{l}\text { Terganggunya stabilitas } \\
\text { bank dan timbulnya } \\
\text { pembiayaan macet }\end{array}$ \\
\hline $\begin{array}{l}\text { B. Risiko } \\
\text { Operasional }\end{array}$ & 17 & $\begin{array}{l}\text { Adanya keterlambatan dalam } \\
\text { penyebaran informasi } \\
\text { kepada staf dari keputusan } \\
\text { pimpinan/rapat }\end{array}$ & 5-10 kali & $\begin{array}{l}\text { Terganggunya alur } \\
\text { komunikasi }\end{array}$ \\
\hline \multirow[t]{7}{*}{ SDM } & 18 & $\begin{array}{l}\text { Adanya persepsi negatif dari } \\
\text { masyarakat terhadap bank }\end{array}$ & 5-10 kali & $\begin{array}{l}\text { Menurunnya kepercayaan } \\
\text { masyarakat terhadap } \\
\text { bank }\end{array}$ \\
\hline & 19 & $\begin{array}{l}\text { Perhitungan PPAP tidak } \\
\text { dilakukan secara rutin }\end{array}$ & $\begin{array}{l}\text { Tidak } \\
\text { pernah }\end{array}$ & $\begin{array}{l}\text { Terganggunya stabilitas } \\
\text { bank dan menimbulkan } \\
\text { kerugian signifikan } \\
\text { terhadap bank }\end{array}$ \\
\hline & 20 & $\begin{array}{l}\text { Kurangnya pengetahuan } \\
\text { SDM bank mengenai } \\
\text { pembiayaan syariah }\end{array}$ & 5-10 kali & $\begin{array}{l}\text { Tidak menimbulkan } \\
\text { masalah berarti }\end{array}$ \\
\hline & 21 & $\begin{array}{l}\text { Kesalahan dalam pencatatan } \\
\text { transaksi/posting }\end{array}$ & 5-10 kali & $\begin{array}{l}\text { Merusak sistem } \\
\text { pencatatan }\end{array}$ \\
\hline & 22 & $\begin{array}{l}\text { Adanya moral hazard } \\
\text { (korupsi, kolusi, pemalsuan) }\end{array}$ & $\begin{array}{l}\text { Tidak } \\
\text { pernah }\end{array}$ & $\begin{array}{l}\text { Kerugian finansial dan } \\
\text { sistemik }\end{array}$ \\
\hline & 23 & Hilangnya berkas dan arsip & $<5$ kali & $\begin{array}{l}\text { Kekurangan data } \\
\text { informasi }\end{array}$ \\
\hline & 24 & $\begin{array}{l}\text { Kurangnya kemampuan } \\
\text { komunikasi dan budaya kerja }\end{array}$ & 5-10 kali & $\begin{array}{l}\text { Terganggunya hubungan } \\
\text { kerja dan terjadi konflik }\end{array}$ \\
\hline Sistem & 25 & $\begin{array}{l}\text { Sistem teknologi informasi } \\
\text { bank mengalami offline atau } \\
\text { error }\end{array}$ & $<5$ kali & $\begin{array}{l}\text { Terganggunya sistem dan } \\
\text { akses data informasi }\end{array}$ \\
\hline Sarana & 26 & $\begin{array}{l}\text { Kegagalan sarana: } \\
\text { komunikasi, listrik, dan air }\end{array}$ & $\begin{array}{c}11-20 \\
\text { kali }\end{array}$ & $\begin{array}{l}\text { Terhambatnya kegiatan } \\
\text { operasional bank dan } \\
\text { terganggunya pelayanan }\end{array}$ \\
\hline
\end{tabular}


27 Rusaknya barang yang disewakan karena pemakaian di luar normal (misal pada ijarah)

\begin{tabular}{|c|c|c|c|c|}
\hline $\begin{array}{l}\text { C. Risiko } \\
\text { Eksternal }\end{array}$ & 29 & $\begin{array}{l}\text { Terjadi bencana alam seperti } \\
\text { gempa bumi, banjir } \\
\text { Adanya kebijakan dari Bank } \\
\text { Indonesia yang merugikan } \\
\text { bank }\end{array}$ & $\begin{array}{l}\text { Tidak } \\
\text { pernah }\end{array}$ & $\begin{array}{l}\text { Perusahaan tidak dapat } \\
\text { beroperasi } \\
\text { Tidak menimbulkan } \\
\text { masalah berarti }\end{array}$ \\
\hline
\end{tabular}
${ }^{a}$ Sumber: Data primer (2013); ${ }^{b}$ Kejadian dalam setahun; ${ }^{\circ}$ Character, Capability, Capital, Condition, Collateral

\subsection{Pengukuran dan Pemetaan Risiko}

\section{ERM 4: Risk Assessment}

Penilaian risiko di BPRS Amanah Ummah dilakukan melalui wawancara dengan direktur, audit internal, kabid marketing, kabid operasional, kabid umum dan personalia, account officer (AO), legal officer (LO), dan ADMP. Hal-hal yang ditanyakan adalah kemungkinan terjadinya risiko yang berkaitan dengan bidang masing-masing dan seberapa besar dampak yang diterima jika risiko tersebut terjadi. Selain wawancara, digunakan juga alat bantu berupa kuesioner terbuka mengenai penilaian risiko pembiayaan dan operasional yang terdapat pada BPRS Amanah Ummah.

Dalam menilai risiko-risiko yang sudah diidentifikasi sebelumnya, ditetapkanlah standar pengukuran yang menjadi indikator ukuran risiko. Pada kasus ini, kemungkinan terjadinya risiko dan dampaknya dinilai berdasarkan diskusi dengan direktur BPRS Amanah Ummah dan ditaksir dengan menggunakan metode aproksimasi. Indikator mengenai kemungkinan terjadinya risiko dapat dilihat pada Tabel 9.

\section{Tabel 9 Indikator kemungkinan terjadinya risiko ${ }^{a}$}

\begin{tabular}{|c|c|c|c|}
\hline Kategori & Keterangan & Probabilitas & Skor \\
\hline Improbable & hampir tidak mungkin terjadi & $<5$ kali per tahun & 1 \\
\hline Remote & kadang terjadi & 5-10 kali per tahun & 2 \\
\hline Occasional & mungkin terjadi & $\begin{array}{l}11-20 \text { kali per } \\
\text { tahun }\end{array}$ & 3 \\
\hline Probable & sangat mungkin terjadi & $\begin{array}{l}21-50 \text { kali per } \\
\text { tahun }\end{array}$ & 4 \\
\hline Frequent & hampir pasti terjadi & $>50$ kali per tahun & 5 \\
\hline
\end{tabular}

Tabel 9 menunjukkan bahwa kemungkinan terjadinya risiko dapat dibagi menjadi 5 skala. Nilai probabilitas ditentukan berdasarkan wawancara dengan pihak direktur BPRS Amanah Ummah sehingga dapat dijadikan indikator pengukuran kemungkinan terjadinya risiko. Selanjutnya, indikator mengenai dampak terjadinya risiko dapat dilihat pada Tabel 10.

Tabel 10 Indikator dampak terjadinya risiko

Tabel 10 Indikator dampak terjadinya risiko ${ }^{\mathrm{a}}$

\begin{tabular}{clc}
\hline \multicolumn{1}{c}{ Kategori } & \multicolumn{1}{c}{ Keterangan } & Skor \\
\hline Negligible & Tidak menimbulkan masalah berarti bagi pihak bank & 1 \\
Marginal & $\begin{array}{l}\text { Menimbulkan masalah kecil yang dapat diatasi dengan } \\
\text { pengelolaan rutin }\end{array}$ & 2 \\
Serious & $\begin{array}{l}\text { Mencegah perusahaan memenuhi tujuannya untuk periode } \\
\text { tertentu saja }\end{array}$ & 3
\end{tabular}


Critical

Catastrophic

Mengakibatkan pihak bank tidak dapat mencapai sebagian tujuan jangka panjang, mengganggu likuiditas bank

Mengakibatkan pihak bank tidak dapat mencapai seluruh tujuan jangka panjang, menyebabkan kebangkrutan,

kematian, atau hukuman pidana

${ }^{a}$ Sumber: Diolah dari Godfrey (2013)

Indikator kerugian untuk dampak terjadinya risiko yang digunakan tidak dikonversi ke dalam nominal rupiah karena penilaian berdasarkan biaya bukanlah merupakan syarat mutlak dalam menilai kerugian (Godfrey 1996). Indikator berdasarkan biaya kerugian yang diterima oleh sebuah perusahaan digunakan berdasarkan kebutuhan. Pada kasus ini, BPRS Amanah Ummah belum memerlukan penilaian kerugian dalam nominal rupiah dan indikator yang digunakan hanya berdasarkan skala kualitatif.

Kemungkinan kejadian risiko dan dampak terjadinya risiko yang telah dijelaskan pada Tabel 8 kemudian dikonversi ke dalam skor berdasarkan indikator pada Tabel 9 dan Tabel 10. Setelah itu, masing-masing skor probabilitas dan skor dampak pada peristiwa risiko dikalikan untuk didapat skor risikonya kemudian dikelompokkan sesuai dengan kategori tingkatan risikonya. Hasil perkalian kemungkinan terjadinya risiko dan dampak terjadinya risiko pada BPRS Amanah Ummah dapat dilihat pada Tabel 11.

Tabel 11 Klasifikasi risiko ${ }^{\mathrm{a}}$

\begin{tabular}{|c|c|c|c|c|c|c|}
\hline No. & Peristiwa risiko & $\begin{array}{c}\text { Sumber } \\
\text { informasi }\end{array}$ & $\begin{array}{c}\text { Skor } \\
\text { Probabilitas } \\
\end{array}$ & $\begin{array}{c}\text { Skor } \\
\text { Dampak }\end{array}$ & $\begin{array}{l}\text { Skor } \\
\text { Total } \\
\end{array}$ & $\begin{array}{l}\text { Tingkat } \\
\text { Risiko }\end{array}$ \\
\hline 1. & Pemalsuan jaminan dari nasabah & LO & 1 & 1 & 1 & Negligible \\
\hline & $\begin{array}{l}\text { Adanya tuntutan hukum pihak lain } \\
\text { atas jaminan dari nasabah }\end{array}$ & LO & 1 & 1 & 1 & Negligible \\
\hline 3. & $\begin{array}{l}\text { Adanya sertifikat ganda (pada } \\
\text { jaminan seperti tanah) }\end{array}$ & $\mathrm{LO}$ & 1 & 1 & 1 & Negligible \\
\hline 4. & Rendahnya nilai jual jaminan & LO & 2 & 2 & 4 & Acceptable \\
\hline & $\begin{array}{l}\text { Adanya kekeliruan dalam penetapan } \\
\text { akad }\end{array}$ & $\begin{array}{l}\text { AO dan } \\
\text { LO }\end{array}$ & & & & \\
\hline 6. & $\begin{array}{l}\text { Keterlambatan pihak bank dalam } \\
\text { memproses pengajuan pembiayaan } \\
\text { nasabah }\end{array}$ & $\mathrm{AO}$ & 2 & 2 & 4 & Acceptable \\
\hline & $\begin{array}{l}\text { Kesalahan prosedur dalam melakukan } \\
\text { proses pembiayaan }\end{array}$ & $\begin{array}{c}\text { Audit } \\
\text { internal }\end{array}$ & 2 & 2 & 4 & Acceptable \\
\hline & $\begin{array}{l}\text { Kurangnya follow-up dari pihak bank } \\
\text { kepada nasabah yang diberikan } \\
\text { pembiayaan }\end{array}$ & $\mathrm{AO}$ & 2 & 2 & 4 & Acceptable \\
\hline & $\begin{array}{l}\text { Terlambatnya pihak bank dalam } \\
\text { menangani pembiayaan yang } \\
\text { bermasalah }\end{array}$ & $\begin{array}{c}\text { Audit } \\
\text { internal }\end{array}$ & 2 & 2 & 4 & Acceptable \\
\hline & $\begin{array}{l}\text { Kurangnya pengetahuan nasabah } \\
\text { pembiayaan akan produk dan prinsip } \\
\text { pembiayaan syariah }\end{array}$ & Direktur & 4 & 2 & 8 & Undesirable \\
\hline & $\begin{array}{l}\text { Adanya pemalsuan data dan } \\
\text { ketidakjujuran dari nasabah }\end{array}$ & $\mathrm{AO}$ & 3 & 3 & 9 & Undesirable \\
\hline & $\begin{array}{l}\text { Pihak bank gagal/kurang teliti dalam } \\
\text { menganalisis aspek } 5 \mathrm{C}^{\mathrm{b}} \text { dari nasabah }\end{array}$ & Direktur & 3 & 3 & 9 & Undesirable \\
\hline & $\begin{array}{l}\text { Nasabah mengalami gagal bayar } \\
\text { karena usahanya bangkrut }\end{array}$ & Direktur & 3 & 4 & 12 & Undesirable \\
\hline 14. & $\begin{array}{l}\text { Nasabah mengalami gagal bayar } \\
\text { karena usahanya mengalami } \\
\text { kegagalan panen/terkena bencana } \\
\text { alam }\end{array}$ & Direktur & 3 & 4 & 12 & Undesirable \\
\hline
\end{tabular}


15. Nasabah terlambat dalam mengembalikan pembiayaan yang diberikan oleh bank

16. Nasabah mengalami gagal bayar karena karakter buruk dan faktor moral (moral hazard) nasabah

17. Rusaknya barang yang disewakan (misal pada ijarah)

18. Kurangnya pengetahuan SDM bank mengenai prinsip dan praktik pembiayaan syariah

19. Hilangnya berkas dan arsip

20. Kurangnya kemampuan komunikasi dan budaya kerja

21. Sistem teknologi informasi bank mengalami offline atau error

22. Perhitungan PPAP tidak dilakukan secara rutin

23. Adanya keterlambatan dalam penyebaran informasi kepada staf dari keputusan pimpinan/rapat

24. Adanya persepsi negatif dari masyarakat terhadap bank

25. Kesalahan dalam pencatatan transaksi/posting

26. Adanya moral hazard (korupsi, kolusi, pemalsuan) dari SDM bank

27. Kegagalan sarana: komunikasi, listrik, dan air

28. Adanya kebijakan dari Bank Indonesia yang merugikan bank

29. Terjadi bencana alam (gempa bumi, banjir)

a Sumber: Data primer (2013); ${ }^{\mathrm{b}}$ Character, Capability, Capital, Condition, Collateral

Setelah diklasifikasikan, risiko-risiko tersebut dapat dipetakan. Pemetaan risiko digolongkan ke dalam 4 tingkatan risiko yang terdiri dari tingkatan negligible, acceptable, undesirable, dan unacceptable (Godfrey 1996). Hasil pemetaan risiko ditunjukkan oleh Tabel 12.

Tabel 12 Hasil pemetaan risiko ${ }^{a}$

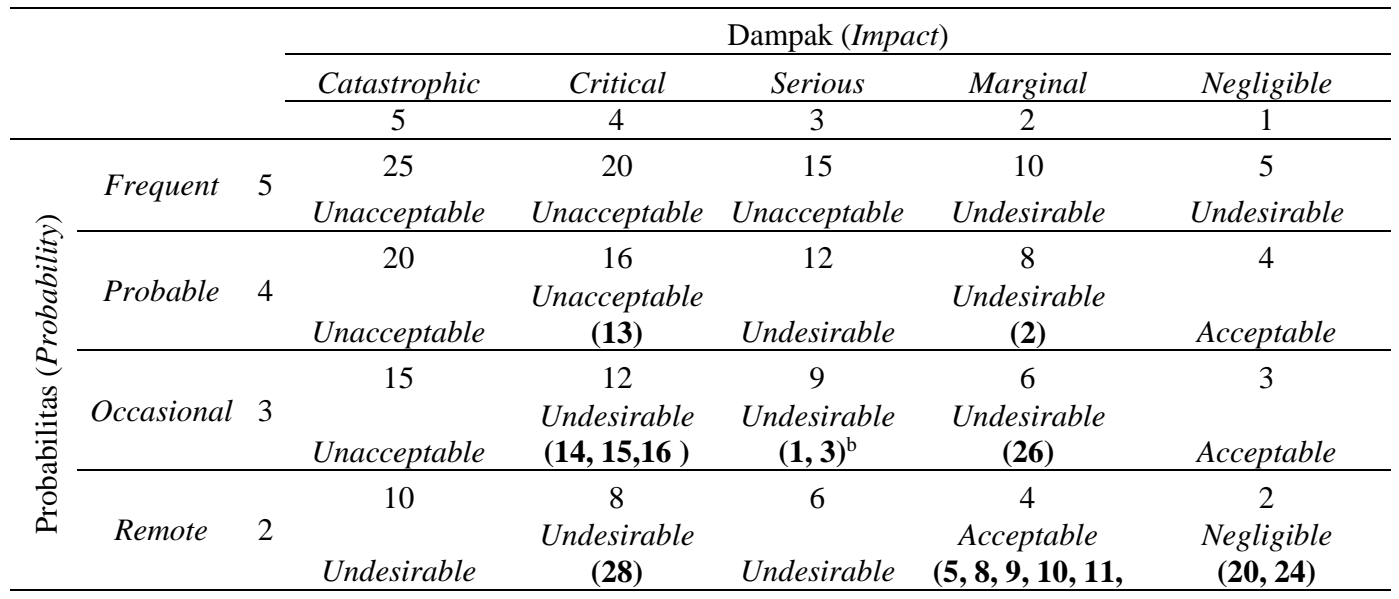




\begin{tabular}{|c|c|c|c|c|c|}
\hline & \multicolumn{5}{|c|}{$12,17,18,21)$} \\
\hline Improbable 1 & $\begin{array}{c}5 \\
\text { Undesirable }\end{array}$ & $\begin{array}{c}4 \\
\text { Acceptable } \\
\text { (22) }\end{array}$ & $\begin{array}{c}3 \\
\text { Acceptable } \\
\text { (19) }\end{array}$ & $\begin{array}{c}2 \\
\text { Negligible } \\
(\mathbf{2 3}, \mathbf{2 5})\end{array}$ & $\begin{array}{c}1 \\
\text { Negligible } \\
(\mathbf{4 , 6}, \mathbf{7 , 2 7 , 2 9 )}\end{array}$ \\
\hline
\end{tabular}

${ }^{\mathrm{a}}$ Sumber: Data primer $(2013) ;{ }^{\mathrm{b}}(\mathbf{X})=$ Nomor risiko (Tabel 8)

Tabel 12 menunjukkan pemetaan risiko dengan 4 tingkatan risiko yang berbeda. Penjelasan mengenai masing-masing risiko sesuai dengan tingkatannya yaitu sebagai berikut:

1. Tingkat Negligible.

Risiko-risiko yang termasuk ke dalam tingkatan ini adalah pemalsuan jaminan nasabah, tuntutan hukum pihak lain atas jaminan nasabah, jaminan bersertifikat ganda, kurangnya pengetahuan SDM bank mengenai prinsip pembiayaan syariah, hilangnya berkas dan arsip, kurangnya kemampuan komunikasi dan budaya kerja, sistem teknologi informasi offline, rusaknya barang yang disewakan pada produk pembiayaan ijarah, dan adanya kebijakan Bank Indonesia yang kurang menguntungkan pihak bank. Risiko-risiko tersebut masuk ke dalam tingkatan negligible karena jarang terjadi dan bila terjadi dampaknya tidak terlalu merugikan bagi perusahaan sehingga dapat diatasi oleh perbaikan dan pengelolaan rutin.

2. Tingkat Acceptable.

Rendahnya nilai jual kembali jaminan, adanya kekeliruan dalam penetapan akad, keterlambatan pihak bank dalam memproses pengajuan pembiayaan nasabah, kesalahan prosedur dalam melakukan proses pembiayaan, kurangnya follow-up dari pihak bank kepada nasabah yang diberikan pembiayaan, terlambatnya pihak bank dalam menangani pembiayaan bermasalah, keterlambatan dalam penyebaran informasi keputusan kepada karyawan, adanya persepsi negatif dari masyarakat kepada bank, perhitungan PPAP tidak dilakukan secara rutin, kesalahan dalam pencatatan transaksi, dan adanya moral hazard (korupsi, kolusi, pemalsuan) dari SDM bank merupakan risikorisiko yang termasuk dalam tingkatan ini. Jika risiko ini terjadi, proses pembiayaan dan kegiatan operasional masih dapat berjalan walau agak terhambat dari jadwal dan target yang telah ditetapkan.

3. Tingkat Undesirable.

Risiko-risiko yang terkandung dalam tingkatan ini adalah pemalsuan data dan ketidakjujuran nasabah, kurangnya pengetahuan nasabah akan produk dan prinsip pembiayaan syariah, kurang telitinya pihak bank dalam menganalisis aspek 5C nasabah, nasabah mengalami gagal bayar karena usahanya mengalami kebangkrutan, gagal panen atau mengalami bencana alam, nasabah terlambat dalam mengembalikan pembiayaan yang diberikan oleh bank, kegagalan sarana, dan terjadinya bencana alam seperti gempa bumi dan banjir. Risiko-risiko tersebut harus diwaspadai karena dapat menimbulkan kerugian yang cukup signifikan pada bank. Salah satu risiko yang paling tinggi yaitu nasabah yang gagal bayar/default karena usahanya mengalami kebangkrutan atau terkena bencana alam. Nasabah yang tidak mampu membayar kewajibannya karena alasan tersebut masih dapat dimaklumi oleh bank walaupun tetap harus dilakukan berbagai tindakan untuk mengatasinya. Kejadian gagal bayar ini akan menimbulkan kerugian pada bank sejumlah pembiayaan/kewajiban yang belum dibayarkan oleh nasabah. Hal tersebut dapat mempengaruhi stabilitas keuangan bank jika pembiayaan yang diberikan kepada nasabah termasuk ke dalam jumlah yang besar.

4. Tingkat Unacceptable. 
Nasabah yang mengalami gagal bayar/default karena karakter buruk dan faktor moral (moral hazard) termasuk ke dalam risiko yang tinggi dan memberikan pengaruh yang signifikan sehingga harus mendapat prioritas utama. Walaupun pada tingkat undesirable terdapat juga potensi risiko nasabah gagal bayar, sumber risikonya berbeda. Risiko gagal bayar akibat karakter buruk nasabah memiliki nilai risiko yang lebih tinggi karena memiliki kemungkinan yang lebih besar menjadi pembiayaan macet. Hal itu disebabkan syarat utama lancarnya proses pembiayaan yakni kemauan untuk membayar dan saling percaya (trust) sudah tidak ada lagi.

\subsection{Potensi Kerugian Pembiayaan Sektor Pertanian di BPRS Amanah Ummah}

Perhitungan potensi kerugian pembiayaan ini menggunakan asumsi probability default yang telah ditetapkan oleh BPRS Amanah Ummah dalam penentuan persentase kerugian untuk masing-masing kualitas pembiayaan. Kualitas pembiayaan dibagi menjadi 4 tingkatan, yaitu:

1. Pembiayaan Lancar (L), yaitu pembiayaan berjalan yang belum jatuh tempo dan angsurannya sesuai dengan jadwal serta jumlah nominal yang ditetapkan.

2. Pembiayaan Kurang Lancar (KL), yaitu pembiayaan berjalan yang belum jatuh tempo dan angsurannya tidak sesuai dengan jadwal serta jumlah nominal yang ditetapkan.

3. Pembiayaan Diragukan (D), yaitu pembiayaan yang sudah jatuh tempo tetapi belum dilunasi dan pembayaran angsuran masih berjalan, namun tidak sesuai dengan jadwal serta jumlah nominal yang telah ditetapkan.

4. Pembiayaan Macet (M), yaitu pembiayaan yang telah jatuh tempo lebih dari 3 periode angsuran tetapi belum terlunasi serta tidak pernah lagi ada pembayaran angsuran.

Penentuan kemungkinan nasabah macet menggunakan distribusi Poisson dengan asumsi tingkat kepercayaan 96\%. Asumsi tersebut diambil untuk mengestimasi risiko pembiayaan pada pelaksanaan operasional pembiayaan perusahaan. Terdapat 5 langkah dalam menghitung potensi kerugian pembiayaan.

\section{Langkah 1: Pengelompokan eksposur dalam band (kelompok).}

Pada periode tahun 2012, nasabah pada sektor pertanian yang mendapatkan pembiayaan dari BPRS Amanah Ummah sejumlah 21 orang nasabah yang terbagi ke dalam 2 skema pembiayaan (20 orang nasabah murabahah dan 1 orang nasabah ijarah). Eksposur/baki debet terkecil dari kedua skema pembiayaan tersebut yaitu Rp200 000 dan terbesarnya yaitu Rp944 444 444. Pengelompokan berdasarkan sebaran data baki debet semua nasabah sektor pertanian dapat dibagi ke dalam 4 band (kelompok) yaitu band Rp50 000 (Rp50 000 - Rp5 000 000), band Rp5 000000 (Rp5 000001 - Rp50 000 000), band Rp50 000000 (Rp 50000001 - Rp500 000 000), dan band Rp500 000000 (Rp500 000001 Rp1 000000 000). Jumlah nasabah yang dikelompokkan pada masing-masing band dapat dilihat pada Tabel 13.

Tabel 13 Jumlah nasabah berdasarkan band ${ }^{\mathrm{a}}$

\begin{tabular}{lcccc}
\hline Band & Rp50 ribu Rp5 juta & Rp50 juta & $\begin{array}{c}\text { Rp500 } \\
\text { juta }\end{array}$ \\
\hline $\begin{array}{l}\text { Jumlah } \\
\text { Nasabah }^{\text {b }}\end{array}$ & 1 & 15 & 4 & 1 \\
\hline a Sumber: BPRS Amanah Ummah (diolah, 2013); ${ }^{\text {b Orang }}$
\end{tabular}


Tabel 13 menjelaskan bahwa nasabah pembiayaan sektor pertanian sebagian besar berada pada band Rp5 000000 yang berkisar antara Rp5 000001 sampai Rp50 000 000. Jumlah nasabah pada band tersebut sebanyak 15 orang (71.43\%). Di samping itu, nasabah pembiayaan sektor pertanian paling sedikit dengan 1 orang $(4.76 \%)$, terdapat pada band Rp50 000 dan band Rp500 000000.

\section{Langkah 2: Perhitungan probability default dan expected loss.}

Pada BPRS Amanah Ummah, nilai probability default ditentukan dari peluang macet nasabah yang nilainya telah ditetapkan oleh BPRS Amanah Ummah berdasarkan kualitas pembiayaan dan data historis pembiayaan nasabah. Kualitas pembiayaan nasabah dibagi menjadi 4 kelompok, yaitu pembiayaan yang kualitasnya lancar memiliki probability default sebesar $0.5 \%$, kualitas kurang lancar sebesar 10\%, kualitas diragukan sebesar $50 \%$, dan kualitas macet sebesar $100 \%$. Berikutnya, expected loss dihitung dari hasil perkalian nilai eksposur/baki debet/Loss Given Default (LGD) dengan peluang macet nasabah (probability default). Expected loss nasabah pada masing-masing band dapat dijelaskan oleh Tabel 14.

Tabel 14 Expected loss nasabah sektor pertanian pada masing-masing band $^{\mathrm{a}}$

\begin{tabular}{|c|c|c|c|c|c|c|}
\hline \multirow[b]{2}{*}{ Band } & \multirow[b]{2}{*}{$\begin{array}{c}\text { Jumlah } \\
\text { Nasabah }^{\text {b }}\end{array}$} & \multicolumn{4}{|c|}{ Kualitas Pembiayaan } & \multirow[b]{2}{*}{$\begin{array}{l}\text { Expected } \\
\text { Loss }\end{array}$} \\
\hline & & Lancar & $\begin{array}{l}\text { Kurang } \\
\text { Lancar }\end{array}$ & Diragukan & Macet & \\
\hline Rp50 000 & 1 & 1 & - & - & - & Rp1 000 \\
\hline Rp5 000000 & 15 & 14 & - & 1 & - & Rp7 690889 \\
\hline Rp50 000000 & 4 & 4 & - & - & - & Rp1 762500 \\
\hline $\begin{array}{l}\text { Rp500 } 000 \\
000\end{array}$ & 1 & 1 & - & - & - & Rp4 722222 \\
\hline Jumlah & 21 & 20 & 0 & 1 & 0 & $\begin{array}{ll}\text { Rp14 } & 176 \\
611 & \end{array}$ \\
\hline
\end{tabular}

a Sumber: BPRS Amanah Ummah (diolah, 2013); ' Orang

Tabel 14 menunjukkan bahwa dari seluruh nasabah yang berjumlah 21 orang, hanya 1 orang yang memiliki pembiayaan bermasalah (berada pada kualitas pembiayaan diragukan). Nasabah tersebut ada pada band Rp5 000000 sedangkan nasabah lainnya yang berjumlah 20 orang berada pada kualitas pembiayaan lancar. Besarnya expected loss pada pembiayaan sektor pertanian ini sebesar Rp14 176611.

\section{Langkah 3: Perhitungan recovery rate dan real loss.}

Nilai real loss berkisar antara 0 (terendah) artinya tidak ada kerugian sama sekali hingga 1 (tertinggi) artinya kerugian yang dihadapi perusahaan sebesar $100 \%$ atau recovery ratenya 0 . Jika bernilai antara 0 dan 1 maka terdapat nilai recovery rate. Nilai ini dapat diperhitungkan dari pencairan jaminan nasabah, nilai baki debet yang dihapusbukukan, atau NPF (nonperforming financing) sektor pertanian.

Pada BPRS Amanah Ummah, pencairan jaminan nasabah jarang dilakukan karena proses ini harus melalui tahapan yang cukup panjang sehingga pihak bank lebih memilih penjadwalan ulang (rescheduling) angsuran dan teguran secara kekeluargaan kepada nasabah yang bermasalah. Di samping itu, untuk nilai baki debet yang dihapusbukukan, BPRS Amanah Ummah belum pernah melakukan tindakan tersebut dan untuk NPF sektor pertanian dapat dilihat dari persentase besarnya kegagalan nasabah dalam melaksanakan kewajibannya kepada bank. Pada tahun 2012, NPF sektor pertanian di BPRS Amanah Ummah sebesar $0.782 \%$ dari total baki debet nasabah sektor pertanian yang 
pembiayaannya bermasalah. Selanjutnya, dari informasi nilai recovery rate, nilai real loss dapat diketahui yaitu sebesar 0.99218 (dengan real loss $=1$-nilai recovery rate $=1$ $0.00782=0.99218)$.

\section{Langkah 4: Penentuan jumlah nasabah macet pada tingkat kepercayaan $96 \%$.}

Pada metode creditrisk+, jumlah nasabah macet dapat dihitung dengan alat bantu analisis statistik yang menggunakan distribusi Poisson. Sebelum menentukan jumlah nasabah macet, dihitung nilai $\mathrm{m}=\lambda=\mathrm{nj}$, dimana $\mathrm{nj}(\lambda)$ merupakan expected loss individual band yang menunjukkan tingkat macet nasabah per 1 rupiah dalam masing-masing band dengan tingkat kepercayaan $96 \%$.

Pengolahan sebaran $\mathrm{n}$-default dengan distribusi Poisson menghasilkan jumlah nasabah yang berpeluang macet untuk periode berikutnya pada tingkat kepercayaan $96 \%$. Penjelasan mengenai jumlah nasabah yang default (n-default) dengan distribusi Poisson dapat dilihat pada Tabel 15 .

Tabel 15 Jumlah nasabah default berdasarkan n-default distribusi Poisson ${ }^{\text {a }}$

\begin{tabular}{|c|c|c|c|c|c|c|c|c|}
\hline \multirow[b]{2}{*}{$\begin{array}{l}\text { Kelas } \\
(\mathrm{Lj})\end{array}$} & \multicolumn{2}{|c|}{ Band $\mathrm{Rp} 50$ ribu } & \multicolumn{2}{|c|}{ Band Rp5 juta } & \multicolumn{2}{|c|}{ Band Rp50 juta } & \multicolumn{2}{|c|}{ Band Rp500 juta } \\
\hline & $\operatorname{nj}(\lambda)$ & $\begin{array}{c}\text { n-default } \\
(\alpha=4 \%)\end{array}$ & $\operatorname{nj}(\lambda)$ & $\begin{array}{c}\text { n-default } \\
(\alpha=4 \%)\end{array}$ & $\operatorname{nj}(\lambda)$ & $\begin{array}{c}\text { n-default } \\
(\alpha=4 \%)\end{array}$ & $\operatorname{nj}(\lambda)$ & $\begin{array}{c}\mathrm{n}- \\
\text { default } \\
(\alpha=4 \%)\end{array}$ \\
\hline 1 & - & - & 0.013 & 0 & 0.012 & 0 & - & - \\
\hline 2 & - & - & 0.012 & 0 & 0.006 & 0 & 0.005 & 0 \\
\hline 3 & - & - & 0.009 & 0 & 0.004 & 0 & - & - \\
\hline 4 & 0.005 & 0 & 0.019 & 0 & - & - & - & - \\
\hline 5 & - & - & - & - & - & - & - & - \\
\hline 6 & - & - & 0.208 & 1 & - & - & - & - \\
\hline 7 & - & - & - & - & - & - & - & - \\
\hline 8 & - & - & - & - & - & - & - & - \\
\hline 9 & - & - & - & - & - & - & - & - \\
\hline 10 & - & - & 0.015 & 0 & - & - & - & - \\
\hline 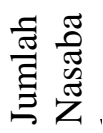 & & 0 & & 1 & & 0 & & \\
\hline
\end{tabular}

a Sumber: Data primer (diolah, 2013)

Tabel 15 memperlihatkan bahwa pada pembiayaan sektor pertanian hanya terdapat 1 nasabah $(4.76 \%)$ berpeluang macet. Nasabah tersebut berada pada band Rp5 000000 . Jumlah ini sama dengan jumlah nasabah bermasalah yang terdapat pada keseluruhan data nasabah pembiayaan sektor pertanian di BPRS Amanah Ummah.

\section{Langkah 5: Perhitungan potensi kerugian pembiayaan.}

Perhitungan potensi kerugian pembiayaan yang disalurkan oleh BPRS Amanah Ummah ini dilakukan untuk mengetahui besarnya potensi kerugian yang akan dihadapi bank pada periode berikutnya dalam nominal rupiah. Besarnya potensi kerugian pembiayaan dapat diperoleh dari jumlah hasil perkalian antara $\mathrm{Lj}$ x real loss $\mathrm{x} \mathrm{n}$-default $\mathrm{x}$ nominal tiap band. Lj menunjukkan kelas pada masing-masing band dan real loss diketahui sebesar 0.99218 untuk semua band. Nilai potensi kerugian pembiayaan pada masing-masing band dapat dilihat pada Tabel 16. 
Tabel 16 Nilai potensi kerugian pembiayaan masing-masing band $^{\mathrm{a}}$

\begin{tabular}{ll}
\hline Band & Potensi kerugian \\
\hline Rp50 000 & Rp0 \\
Rp5 000 000 & Rp29 765 400 \\
Rp50 000 000 & Rp0 \\
Rp500 000 000 & Rp0 \\
\hline Jumlah & Rp29765 400 \\
\hline Sumber: Data primer (diolah, 2013) &
\end{tabular}

Tabel 16 menunjukkan bahwa potensi kerugian pembiayaan untuk sektor pertanian sejumlah Rp29 765 400. Nilai tersebut muncul dari 1 orang nasabah yang berpeluang macet pada band Rp5 000 000. Potensi kerugian ini termasuk rendah jika dibandingkan dengan total baki debetnya, yaitu hanya 1.84\% dari Rp1 615500768.

Potensi kerugian pembiayaan untuk sektor pertanian di BPRS Amanah Ummah pada tahun 2012 berdasarkan perhitungan dengan metode creditrisk+ termasuk rendah karena tidak menimbulkan kerugian signifikan jika dibandingkan secara nominal rupiah terhadap keseluruhan pendapatan perusahaan. Menurut hasil perhitungan potensi kerugian pembiayaan, dapat dianalisis bahwa risiko pembiayaan pada sektor pertanian tidak selalu mengandung risiko yang tinggi. Pada kasus ini, risiko pembiayaan syariah untuk sektor pertanian relatif rendah dilihat dari proporsi potensi kerugiannya terhadap keseluruhan baki debet yang disalurkan pada sektor pertanian. Risiko yang rendah ini disebabkan oleh 3 alasan. Pertama, pengaruh produk pembiayaan yang digunakan, yaitu 95.24\% menggunakan produk murabahah. Produk murabahah merupakan produk pembiayaan jual beli dimana aspek risikonya tidak terlalu berkaitan dengan risiko bisnis nasabah secara langsung sehingga risikonya lebih rendah. Kedua, pengaruh skala usaha pertanian nasabah yang diberikan pembiayaan. Pelaku usaha pertanian yang diberikan pembiayaan oleh BPRS Amanah Ummah rata-rata berada pada skala usaha menengah atau usaha yang sudah berkembang. Di samping itu, mayoritas nasabah sudah pernah mendapatkan pembiayaan dari BPRS Amanah Ummah sehingga terdapat kepercayaan dari pihak bank. Alasan ketiga yaitu karena hampir keseluruhan nasabah pembiayaan sektor pertanian memiliki usaha atau penghasilan di luar usaha pertanian itu sendiri sehingga kemampuan membayarnya lebih tinggi dan kualitas pembiayaannya cenderung lancar.

\subsection{Tindakan Mitigasi Risiko}

ERM 5: Risk Response

BPRS Amanah Ummah memahami bahwa pengelolaan risiko sangat penting dalam sebuah perusahaan dan telah menyusun beberapa tindakan mitigasi sebagai respon terhadap risiko. Tindakan mitigasi risiko tersebut sebagai berikut:

1. Melakukan ekspansi pembiayaan secara selektif dan fokus kepada target pasar yang telah ditetapkan.

2. Melakukan monitoring dan evaluasi pembiayaan secara terus menerus dan berkesinambungan.

3. Membentuk cadangan pembentukan penyisihan aktiva produktif (PPAP) yang memadai. 
4. Mengasuransikan aktiva tetap dan aktivitas kas dengan pihak asuransi Takaful.

5. Melakukan sosialisasi dan internalisasi manajemen risiko secara kontinyu untuk menumbuhkan risk awareness pada seluruh karyawan baik melalui pengkinian Standard Operational Procedure (SOP) maupun dalam bentuk pelatihan terkait manajemen risiko.

6. Mengoptimalkan peran Dewan Pengawas Syariah (DPS) dalam pengawasan produk dan operasional bank agar tetap sesuai dengan prinsip-prinsip syariah (sharia compliance).

7. Menetapkan limit untuk portofolio bank dan limit transaksional seperti limit pembiayaan.

8. Menerbitkan laporan portofolio pembiayaan setiap bulan untuk memberikan informasi mengenai perkembangan portofolio dan kualitas pembiayaan.

Tindak lanjut yang dilakukan pihak BPRS Amanah Ummah dalam menangani pembiayaan bermasalah yaitu terlebih dahulu menganalisis penyebab terjadinya mengapa nasabah tersebut mengalami pembiayaan bermasalah. Jika alasan terjadinya akibat karakter buruk nasabah dan tidak adanya willingness to pay (keinginan untuk membayar) dari nasabah maka pihak bank akan menarik jaminan nasabah dan diproses agar dapat dicairkan sehingga mengganti kerugian yang diterima bank. Namun, jika alasan terjadinya karena terdapat gangguan internal usaha nasabah, bank akan melakukan rescheduling pada nasabah. Lain hal jika alasan terjadinya akibat musibah, bencana alam, dan bangkrutnya usaha maka pihak bank akan menempuh tindakan restrukturisasi dengan memberikan bantuan dana yang sumbernya berasal dari cadangan PPAP.

Beberapa kemungkinan respon atas risiko adalah menerima risiko (accept), mengurangi risiko (reduce), berbagi risiko (transfer), menghindari risiko (avoid), dan menghilangkan risiko (remove). Terdapat beberapa kemungkinan respon dan tindakan mitigasi risiko yang dapat diambil oleh BPRS Amanah Ummah. Respon terhadap risiko ini dianalisis berdasarkan setiap peristiwa risiko yang ada. Kemungkinan respon dan tindakan mitigasi risiko tersebut dapat dilihat pada Tabel 17.

Tabel 17 Risk response yang dapat diambil oleh BPRS Amanah Ummaha

\begin{tabular}{|c|c|c|c|}
\hline No. & Peristiwa Risiko & Respon Risiko & Tindakan Mitigasi \\
\hline \multicolumn{4}{|c|}{ A. Risiko Pembiayaan } \\
\hline & $\begin{array}{l}\text { Adanya pemalsuan } \\
\text { data dan } \\
\text { ketidakjujuran dari } \\
\text { nasabah }\end{array}$ & Mengurangi & $\begin{array}{l}\text { Merekrut SDM ahli hukum, menciptakan } \\
\text { hubungan baik dengan nasabah }\end{array}$ \\
\hline 2. & $\begin{array}{l}\text { Kurangnya } \\
\text { pengetahuan nasabah } \\
\text { pembiayaan syariah }\end{array}$ & Mengurangi & $\begin{array}{l}\text { Memberikan penjelasan kepada nasabah } \\
\text { mengenai informasi produk dan prinsip } \\
\text { pembiayaan syariah }\end{array}$ \\
\hline 3. & $\begin{array}{l}\text { Pihak bank gagal } \\
\text { menganalisis aspek } \\
5 \mathrm{C}^{\mathrm{b}}\end{array}$ & Mengurangi & $\begin{array}{l}\text { Melakukan pelatihan dan pembinaan, } \\
\text { peningkatan peran AO yang juga menjadi } \\
\text { investment manager }\end{array}$ \\
\hline & $\begin{array}{l}\text { Pemalsuan jaminan } \\
\text { nasabah }\end{array}$ & Mengurangi & $\begin{array}{l}\text { Merekrut SDM ahli hukum, membina } \\
\text { hubungan baik }\end{array}$ \\
\hline & $\begin{array}{l}\text { Rendahnya nilai jual } \\
\text { jaminan }\end{array}$ & Mengurangi & $\begin{array}{l}\text { Merekrut SDM ahli hukum dalam } \\
\text { mentaksasi jaminan }\end{array}$ \\
\hline & $\begin{array}{l}\text { Adanya tuntutan } \\
\text { hukum }\end{array}$ & Mengurangi & Merekrut SDM ahli hukum \\
\hline
\end{tabular}


7. Adanya sertifikat ganda

8. Adanya kekeliruan akad

9. Bank terlambat memproses pengajuan pembiayaan

10. Kesalahan prosedur dalam proses pembiayaan

11. Kurangnya follow-up dari pihak bank

12. Terlambatnya pihak bank dalam menangani pembiayaan yang bermasalah

13. Nasabah mengalami gagal bayar karena karakter buruk

14. Nasabah mengalami gagal bayar karena usahanya mengalami kebangkrutan

15. Nasabah mengalami gagal bayar karena usahanya gagal panen/terkena bencana alam

16. Nasabah terlambat dalam mengembalikan pembiayaan

B. Risiko Operasional

17. Keterlambatan penyebaran hasil keputusan pimpinan/rapat

18. Adanya persepsi negatif dari masyarakat terhadap bank

19. Perhitungan PPAP tidak dilakukan secara rutin

20. Kurangnya pengetahuan SDM bank mengenai pembiayaan syariah

21. Kesalahan dalam pencatatan transaksi/posting
Mengurangi Merekrut SDM ahli hukum

Menghindari Penetapan prosedur yang jelas dan pengecekan ulang

Mengurangi Pemeriksaan dan pengendalian secara ketat oleh kabid marketing, penetapan SOP yang jelas

Menghindari Penerapan SOP secara jelas dan pemeriksaan rutin oleh audit internal di setiap tahap proses pembiayaan

Mengurangi Adanya pengawasan dan pengecekan secara ketat dari audit internal agar AO melakukan follow-up rutin

Menghindari Penerapan SOP secara tegas dan adanya peringatan dini jika terdapat nasabah yang mengalami gejala pembiayaan bermasalah

Mengurangi Melakukan analisis mendalam sebelum memberikan pembiayaan kepada nasabah, mencairkan jaminan

Mengurangi Melakukan analisis kelayakan usaha lebih spesifik dan kontrol terhadap perkembangan usaha yang dijalankan nasabah, melakukan tindakan rescheduling

Menerima Mengestimasi cadangan PPAP dengan akurat, menempuh tindakan restrukturisasi yang sumber dananya berasal dari cadangan PPAP tersebut

Mengurangi Melakukan pembinaan dan pengawasan berkala dan langsung mendatangi ke tempat nasabah
Mengurangi Diadakan rapat rutinan seluruh karyawan dan ada papan informasi yang dapat dilihat oleh seluruh karyawan

Mengurangi Pembentukan kotak kritik saran dari nasabah, penanganan komplain nasabah dengan sigap, mendeteksi kemungkinan terjadinya fraud internal

Menghindari Melakukan perhitungan rutin dan diawasi oleh audit internal, sistem komputerisasi dalam perhitungan PPAP

Mengurangi Mengadakan kuliah dan pelatihan rutin mengenai prinsip dan praktik pembiayaan syariah kepada seluruh karyawan, merekrut SDM handal

Menghindari Adanya SOP yang jelas, melakukan pengecekan ulang sebelum posting 
22. Adanya moral hazard Mengurangi dari SDM bank

23. Hilangnya berkas dan arsip

24. Kurangnya kemampuan komunikasi dan budaya kerja

25. Sistem teknologi informasi bank mengalami offline

26. Kegagalan sarana

27. Rusaknya barang yang disewakan
Mengurangi Pemasangan CCTV dalam kantor, pembuatan SOP yang jelas dan tegas, dan pengawasan SOP secara ketat

Mengurangi Memiliki berkas/arsip lebih dari 1 salinan/softcopy

Mengurangi Pelatihan secara berkala, mengadakan acara kebersamaan untuk seluruh karyawan

Mengurangi Merekrut SDM ahli IT, memiliki lebih dari 1 jaringan internet, dan pemeliharaan rutin

Menghilangkan Menyediakan genset dan pemeliharaan rutin

Menghindari Mengasuransikan barang, ada perjanjian dan tranfer jelas dalam akad, mencadangkan dana antisipasi kerusakan barang

C. Risiko Eksternal

28. Terjadi bencana alam

Transfer

Mendaftarkan pada asuransi

29. Adanya kebijakan BI

Menerima

Menyesuaikan kebijakan

BI tersebut dengan serangkaian kebijakan internal pada bank bank

a Sumber: Data primer (2013); ${ }^{\mathrm{b} C h a r a c t e r, ~ C a p a b i l i t y, ~ C a p i t a l, ~ C o n d i t i o n, ~ C o l l a t e r a l ~}$

\section{ERM 6: Control Activities}

Tindakan pengendalian dilakukan untuk meminimalisir kerugian yang ditimbulkan oleh risiko dan menjamin respon terhadap risiko berjalan dengan efektif. Pengendalian yang dilakukan dapat berupa deskripsi kerja yang jelas untuk masing-masing karyawan, pengawasan yang ketat terhadap SOP, dokumentasi yang baik di tiap bagian, dan adanya pelaksanaan internal audit secara berkala dalam kurun waktu tertentu. Perlu ditambahkan bahwa faktor pengendalian yang kuat secara internal dan eksternal mutlak dibutuhkan. Jumlah dan skala bisnis bank yang beragam menyebabkan risiko yang dihadapi akan relatif beragam sehingga penguatan fungsi pengawasan regulator sebagai bagian dari early warning system akan menjadi kunci dalam mengantisipasi munculnya risiko yang mungkin terjadi di masa yang akan datang.

\section{ERM 7: Information and Communication}

Tindakan mitigasi risiko juga harus didukung dengan komunikasi dan alur informasi yang efektif dan efisien. Setiap informasi yang relevan dan terkait kemudian diidentifikasi, diproses, dan dikomunikasikan dengan deskripsi yang jelas agar setiap individu dalam perusahaan mampu melaksanakan tanggung jawabnya. Kegiatan komunikasi termasuk ke dalam pihak internal bank, nasabah bank, para pemegang saham bank, pihak regulator dan pengawas, dan pihak eksternal lainnya.

Pada pihak internal bank, komunikasi dan informasi yang dilakukan untuk meminimalisir risiko adalah dengan mengadakan rapat rutin mingguan dalam membahas kinerja. Selain itu, dapat diadakan acara rutin kebersamaan dalam periode tertentu, misalnya dengan pergi ke luar kota untuk meningkatkan keakraban dan kekompakan tim. Koordinasi antar bidang juga sangat dibutuhkan dalam mengantisipasi adanya kesalahpahaman dan disertai pula pengawasan berkala dari dewan direksi dan audit internal. Sarana komunikasi tambahan seperti papan informasi di kantor juga dapat menjadi fasilitas penyebaran informasi yang mudah diakses seluruh karyawan bank. 
Terkait dengan pemeliharaan hubungan baik dengan nasabah, beberapa tindakan komunikasi dan informasi yang dapat dilakukan pihak bank yaitu dengan:

1. Komunikasi secara reguler dengan nasabah mengenai kelangsungan usaha.

2. Mengirim kartu ucapan ulang tahun, kelahiran anak, hari raya, dan sebagainya.

3. Memberikan informasi seminar, workshop, dan kegiatan lainnya yang berhubungan dengan usaha nasabah atau pembiayaan.

4. Menghubungkan nasabah dengan supplier atau konsumen yang juga nasabah bank.

5. Menyajikan informasi yang faktual dan terkini, misalnya mengenai nisbah bagi hasil dan investasi yang diambil bank atas nama nasabah.

6. Memperbaharui media informasi secara berkala, seperti buletin, brosur, dan website.

Selain pembinaan komunikasi yang baik dengan nasabah, penting juga melakukan pembinaan komunikasi dan penyampaian informasi yang transparan dengan para pemegang saham. Para pemegang saham (di luar kepemilikan saham oleh pengurus BPRS Amanah Ummah) memiliki hak dalam pengambilan keputusan penting dalam perusahaan. Hal ini dilakukan untuk meningkatkan kepercayaan dan mengantisipasi timbulnya kecurigaan dalam pelaksanaan kegiatan operasional bank.

BPRS merupakan lembaga dengan dual regulatory body yang harus memperhatikan jalinan komunikasi dua-arah antara pihak bank dengan Dewan Pengawas Syariah maupun Bank Indonesia. Dewan Pengawas Syariah (DPS) melakukan tindakan pengawasan terhadap sharia compliance yang dilakukan bank agar tidak ada kegiatan yang bertentangan dengan prinsip syariah. Bank Indonesia (BI) melakukan tindakan pengawasan secara umum dan penetapan kebijakan mengenai tata kelola aktivitas bank. Pihak bank juga harus mengirimkan laporan secara berkala baik kepada DPS maupun BI agar dapat dipantau, diperiksa, dan diantisipasi sedini mungkin jika ada deteksi ketidaksesuaian dengan prinsip dan kebijakan yang telah ditetapkan.

\section{ERM 8: Monitoring}

Kegiatan monitoring dapat dilakukan melalui proses manajemen yang sedang berjalan dan dievaluasi secara rutin. Pada BPRS Amanah Ummah, kegiatan monitoring dalam pembiayaan dilakukan karena beberapa alasan penting, seperti:

1. Pembiayaan merupakan hubungan bisnis bank dengan nasabah dari mulai pembiayaan diberikan sampai pelunasan.

2. Pembiayaan merupakan aktiva produktif yang menghasilkan pengembalian kepada bank.

3. Pembiayaan memberikan porsi terbesar sebagai sumber pendapatan bank.

4. Jika terjadi pembiayaan bermasalah maka akan membebani modal bank sehingga mempengaruhi ekspansi bank atau CAR (Capital Adequacy Ratio) menurun. CAR adalah rasio kecukupan modal seperti diatur Bank Indonesia minimal sebesar 8\%. Pada akhir tahun 2012, CAR BPRS Amanah Ummah sebesar $14.17 \%$. Nilai CAR BPRS Amanah Ummah cukup memadai jika dilihat berdasarkan ketentuan BI tersebut.

Beberapa pihak yang berperan aktif dalam tahap monitoring dan supervisi adalah dewan pengawas syariah (DPS), dewan komisaris, dewan direksi dan audit internal. DPS 
bertugas memenuhi prinsip syariah baik yang berasal dari internal bank maupun eksternal. Dewan komisaris berperan aktif melaksanakan supervisi dan pengawasan terhadap kinerja perusahaan, salah satunya dengan menyelenggarakan rapat rutin mingguan. Dewan direksi bertugas memimpin kegiatan bank sehari-hari dengan kebijakan umum yang telah disetujui oleh dewan komisaris. Dewan direksi juga harus memimpin rapat, menandatangani berkas dan dokumen, menerima laporan kegiatan, mengontrol dan mengawasi likuiditas bank, serta memberikan pertanggungjawaban kepada RUPS atas jalannya usaha bank. Audit internal berperan dalam memantau dan supervisi pada kegiatan pembiayaan yang dilakukan, mengaudit bank secara berkala minimal 6 bulan sekali meliputi neraca, administrasi pembiayaan, dan manajemen bank serta melakukan evaluasi terhadap semua bagian struktur organisasi BPRS Amanah Ummah. Secara umum, BPRS Amanah Ummah sudah melakukan kegiatan monitoring dengan baik dan kegiatan ini sudah menjadi bagian dari tindakan mitigasi risiko. Fokus utama dalam kegiatan monitoring adalah menghindari terjadinya risiko pembiayaan bermasalah atau macet. Terdapat beberapa langkah supervisi dan monitoring yang ditetapkan oleh BPRS Amanah Ummah untuk menghindari terjadinya risiko pembiayaan seperti pembiayaan bermasalah atau macet, yaitu:

1. Supervisi dan monitoring pembiayaan prapencairan.

Pemantauan pembiayaan prapencairan dilakukan dengan menganalisis jenis dan karakter usaha nasabah, karakter nasabah itu sendiri, dan produk/skema pembiayaan yang akan diterapkan pada masing-masing nasabah. Kegiatan pemantauan lainnya juga dapat dilihat dari evaluasi penggunaan modal kerja nasabah, evaluasi laporan keuangan nasabah secara berkala, ketepatan angsuran nasabah (jika pernah mendapatkan pembiayaan sebelumnya), dan kelengkapan dokumen. Kegiatan monitoring juga dilihat dari peninjauan ke lokasi usaha nasabah untuk melihat perkembangan usaha nasabah, kunjungan ke rumah nasabah untuk mengenal lebih dalam karakter nasabah, melakukan aktivitas tertentu dengan nasabah (misal: olahraga bersama), menghadiri undangan nasabah, dan kunjungan ke rekanan/mitra nasabah untuk memeriksa nasabah secara tidak langsung.

2. Supervisi dan monitoring pembiayaan pascapencairan.

Pemantauan pembiayaan pascapencairan dilakukan lebih intensif dan lebih tertib. Tertib administrasi pembiayaan dilakukan berdasarkan kualitas pembiayaan sesuai ketentuan bank. Kegiatan tertib administrasi ini diperlukan untuk mengetahui tingkat kesehatan pembiayaan, pengelolaan akun pembiayaan dan kolektibilitas, pemantauan kesehatan bank, serta perancangan perencanaan penyelesaian pembiayaan bermasalah.

\section{Simpulan dan Saran}

\subsection{Simpulan}

Kegiatan pembiayaan syariah pada sektor pertanian di BPRS Amanah Ummah memiliki risiko seperti risiko pembiayaan dan operasional. Hasil identifikasi risiko pembiayaan dan risiko operasional yang berkaitan dengan sektor pertanian di BPRS Amanah Ummah, baik secara langsung maupun tidak langsung, menghasilkan 29 peristiwa risiko yang terdiri dari 16 peristiwa risiko pembiayaan, 11 peristiwa risiko operasional, dan 2 peristiwa risiko eksternal.

Hasil pengukuran risiko pembiayaan dan risiko operasional yang berkaitan dengan sektor pertanian di BPRS Amanah Ummah menghasilkan pemetaan risiko dengan komposisi yaitu 9 peristiwa risiko dengan tingkatan negligible seperti pemalsuan jaminan dari 
nasabah dan adanya jaminan bersertifikat ganda. Sebelas peristiwa risiko dengan tingkatan acceptable seperti adanya kekeliruan penetapan akad dan kesalahan prosedur dalam proses pembiayaan. Delapan peristiwa risiko dengan tingkatan undesirable seperti adanya pemalsuan data dan ketidakjujuran nasabah serta timbulnya kegagalan sarana. Terdapat pula peristiwa risiko dengan tingkatan unacceptable seperti nasabah mengalami gagal bayar karena karakter buruk dan moral hazard nasabah.

Hasil perhitungan potensi kerugian pembiayaan syariah untuk sektor pertanian di BPRS Amanah Ummah diestimasi sebesar Rp29 765 400. Potensi kerugian ini relatif rendah jika dibandingkan dengan total baki debetnya, yaitu hanya 1.84\% dari Rp 1615500768 .

Terdapat 8 tindakan mitigasi risiko yang telah ditetapkan BPRS Amanah Ummah dan ada pula beberapa kemungkinan respon risiko yang dapat diambil oleh BPRS Amanah Ummah. Salah satu risiko utama dalam pembiayaan adalah pembiayaan bermasalah/macet sehingga tindakan mitigasi risiko yang dapat dilakukan yaitu rescheduling, restrukturisasi, dan pencairan jaminan nasabah. Tindakan mitigasi risiko lainnya juga dianalisis dari aspek kendali aktivitas, alur informasi dan komunikasi, serta pemantauan secara berkala.

Berdasarkan hasil dari penelitian ini, risiko utama dalam pembiayaan sektor pertanian adalah karakter buruk nasabah atau moral hazard bukan karena karakteristik khusus yang hanya terdapat pada sektor pertanian (risiko produksi, risiko eksternal seperti cuaca). Risiko moral hazard dapat terjadi di semua sektor ekonomi, bukan hanya pada sektor pertanian. Implikasi pentingnya yaitu hasil penelitian ini dapat dijadikan acuan bagi pemerintah dalam mendorong lembaga pembiayaan seperti bank untuk lebih meningkatkan alokasi pembiayaan untuk sektor pertanian.

\subsection{Saran}

Saran yang dapat disampaikan dari penelitian ini untuk penelitian selanjutnya yaitu berkaitan dengan beberapa hal berikut:

1. Menganalisis risiko pasar dan pengaruhnya terhadap sektor pertanian, baik secara langsung maupun tidak langsung.

2. Mengembangkan penggunaan metode ERM (Enterprise Risk Management) pada perbankan syariah untuk dapat menganalisis risiko secara komprehensif.

3. Mengkonversi indikator dampak kerugian skala kualitatif ke dalam nominal rupiah agar lebih terukur.

4. Melakukan analisis risiko pembiayaan untuk sektor pertanian pada lembaga keuangan syariah lainnya seperti BMT (Baitul Maal Wa Tamwil) atau BUS (Bank Umum Syariah).

5. Melakukan analisis yang lebih mendalam, misalnya dengan analisis faktor, mengenai penyebab kurang berkembangnya produk pembiayaan lain selain murabahah pada sektor pertanian dan kajian terhadap produk pembiayaan lainnya yang sesuai dengan sektor pertanian.

\section{Daftar Pustaka}

Ashari, Saptana. 2005. Prospek pembiayaan syariah untuk sektor pertanian. Forum Penelitian Agro Ekonomi [Internet]. [Diunduh 2012 Apr 7]; 23(2): 132-147. Tersedia pada: http://pse.litbang.deptan.go.id/ind/pdffiles/FAE23-2e.pdf. 
[BI] Bank Indonesia. 2011. Statistik Perbankan Syariah Juni 2011. Jakarta (ID).

[BI] Bank Indonesia. 2013. Statistik Perbankan Syariah Januari 2013. Jakarta (ID).

[BPRS AU] BPRS Amanah Ummah. 2007. Laporan Tahunan (Annual Report) 2007 BPRS Amanah Ummah. Bogor (ID): IPB.

[BPRS AU] BPRS Amanah Ummah. 2008. Laporan Tahunan (Annual Report) 2008 BPRS Amanah Ummah. Bogor (ID): IPB.

[BPRS AU] BPRS Amanah Ummah. 2010. Laporan Tahunan (Annual Report) 2010 BPRS Amanah Ummah. Bogor (ID): IPB.

[BPRS AU] BPRS Amanah Ummah. 2011. Laporan Tahunan (Annual Report) 2011 BPRS Amanah Ummah. Bogor (ID): IPB.

[BPRS AU] BPRS Amanah Ummah. 2012. Laporan Tahunan (Annual Report) 2012 BPRS Amanah Ummah. Bogor (ID): IPB.

[BPS] Badan Pusat Statistik. 2013. Penduduk 15 Tahun ke Atas yang Bekerja Menurut Lapangan Pekerjaan Utama pada Tahun 2004-2012. Jakarta (ID).

[BPS] Badan Pusat Statistik. 2013. Produk Domestik Bruto Atas Dasar Harga Berlaku Menurut Lapangan Usaha pada Tahun 2004-2012. Jakarta (ID).

Crouchy et al. 2000. Risk Management: Comprehensive Chapters on Market, Credit, and Operational Risk, Features an Integrated VaR Framework, Hedging Strategies for Reducing Risk. New York (US): McGraw-Hill.

CSFB. 1997. Creditrisk+: A Credit Risk Management Framework. London (GB): Credit Suisse First Boston.

[DPKP] Direktorat Pembiayaan Kementerian Pertanian. 2011. Pola Pembiayaan Syariah untuk Sektor Pertanian. Jakarta (ID): Kementerian Pertanian.

Godfrey PS. 1996. Control of Risk: A Guide to the Systematic Management of Risk from Construction. London (GB): Construction Industry Research and Information Assoc.

Hafidhuddin D, Syukur M. 2008. Pembiayaan Syariah dalam Pembangunan Pertanian. Jakarta (ID): Pusat Pembiayaan Pertanian Sekretariat Jenderal Departemen Pertanian.

Karim AA. 2009. Bank Islam : Analisis Fiqih dan Keuangan. Jakarta (ID): Raja Grafindo Persada.

Kountur R. 2008. Mudah Memahami Manajemen Risiko Perusahaan. Jakarta (ID): Penerbit PPM.

Siahaan H. 2009. Manajemen Risiko : Pada Perusahaan dan Birokrasi. Jakarta (ID): Elex Media Komputindo.

Triawan LN. 2008. Risiko portofolio dan potensi kerugian pembiayaan pada BPRS Amanah Ummah dengan metode creditrisk+ [skripsi]. Bogor (ID): Institut Pertanian Bogor. 


\section{Lampiran}

\section{Pengukuran Potensi Kerugian Pembiayaan pada Sektor Pertanian}

Pengukuran potensi kerugian dalam pembiayaan dapat dihitung dengan menggunakan metode creditrisk+. Metode ini menganalisis kegagalan atas risiko default (gagal bayar) sebagai risiko yang harus dihadapi BPRS pada saat nasabah berada pada kondisi sulit atau tidak mampu membayar hutangnya. Pada penelitian ini, hanya difokuskan pada nasabah yang usahanya berada pada sektor pertanian. Metode creditrisk+ merupakan distribusi dari risiko portofolio untuk mencari probabilitas jumlah nasabah yang default dalam 1 periode yang dinyatakan dengan distribusi Poisson. Pada metode creditrisk + , probability default (kemungkinan gagal bayar) yang digunakan berdasarkan statistik data historis dari pengalaman gagal bayar. Model creditrisk + adalah model statistik dari risiko gagal bayar dengan tidak memperhatikan penyebab gagal bayar (CSFB 1997).

Kelebihan metode ini adalah mudah diimplementasikan (Crouhy et al 2000) dan kemudahan ketersediaan data. Metode creditrisk + difokuskan pada estimasi potensi risiko nasabah yang default. Model hanya membutuhkan data probability default, eksposur (nilai baki debet atau nilai saldo pembiayaan yang belum dilunasi pada periode tertentu) dan nilai recovery rate/real loss. Di samping itu, keterbatasan metode creditrisk + terdapat pada beberapa asumsi yaitu risiko pembiayaan tidak berhubungan dengan risiko pasar, besarnya eksposur dari tiap nasabah tetap dan tidak sensitif terhadap perubahan, serta tidak memperhitungkan risiko mitigasi.

Urutan proses perhitungan creditrisk + mengikuti kerangka pemikiran yang diuraikan dalam teknis perhitungan yang sistematis (Crouchy et al 2000). Input yang dibutuhkan dalam metode creditrisk+ adalah data eksposur, probability default, dan recovery rate. Selanjutnya, input tersebut diproses melalui 5 langkah metode creditrisk+ dan menghasilkan output berupa potensi kerugian pembiayaan. Langkah-langkah tersebut yaitu sebagai berikut:

Langkah 1: Pengelompokan eksposur dalam band (kelompok).

Besarnya pembiayaan yang dikeluarkan oleh BPRS berbeda untuk setiap nasabah berdasarkan kelayakan usahanya sehingga penetapan angsuran setiap nasabah juga berbeda-beda. Besarnya angsuran setiap nasabah terdiri dari angsuran pokok dan angsuran marjin. Eksposur dinotasikan dengan Loss Given Default (LGD), merupakan proporsi kerugian kerena nasabah default (gagal bayar), dinyatakan oleh nilai tunggakan angsuran pokok pembiayaan dari setiap nasabah. Bagi nasabah yang tunggakan pokok pembiayaannya sudah lunas, namun masih menyisakan tunggakan angsuran marjin, tidak dihitung sebagai nasabah yang berpotensi menghasilkan risiko pembiayaan. Selanjutnya, untuk mempermudah perhitungan maka eksposur dikelompokkan dalam band. Nasabah dikelompokan berdasarkan nilai eksposur terendah hingga tertinggi kemudian dibagi ke dalam kelas-kelas pada range tertentu.

\section{Langkah 2: Perhitungan probability default dan expected loss.}

Proses selanjutnya yaitu jumlah nasabah yang macet dihitung berdasarkan jenis atau karakteristik kolektibilitas dari masing-masing nasabah. Data kolektibilitas dibuat berdasarkan data historis nasabah dan kemampuan untuk membayar. Ketentuan kolektibilitas pembiayaan dan probability default dapat mengikuti aturan Pembentukan 
Penyisihan Aktiva Produktif (PPAP) bagi BPRS. Namun, dapat pula memakai ketentuan kolektibilitas yang dibuat secara khusus oleh lembaga keuangan yang bersangkutan. Menurut ketentuan BPRS Amanah Ummah, masing-masing kolektibilitas mempunyai probability default sebagai berikut:

1. Kolektibilitas 1, Probability Default-nya : $0.5 \%$.

2. Kolektibilitas 2, Probability Default-nya : $10 \%$.

3. Kolektibilitas 3, Probability Default-nya : 50\%.

4. Kolektibilitas 4, Probability Default-nya : $100 \%$.

Jika telah menentukan LGD dan probability default maka ditentukan expected loss pada setiap kelas (j) di masing-masing band. Expected loss merupakan hasil perkalian antara LGD dengan probability default. Perhitungan rumus tersebut dapat dilihat pada formulasi (1).

$$
\mathrm{ELj}=\sum_{i=1}^{m} \sum_{j=1}^{n} L G D \mathrm{ij} . \mathrm{Pij}
$$

Keterangan :

Elj $\quad=$ Expected loss nasabah pada kelas ke-j

LGDij = Loss Given Default (LGD) ke-I pada kelas ke-j

Pij = Probabilty default nasabah ke-I pada kelas ke-j

$\mathrm{m} \quad=$ Jumlah nasabah di dalam setiap band

$\mathrm{n} \quad=$ Jumlah kelas di dalam setiap band

Perhitungan selanjutnya adalah menentukan expected loss individual dalam setiap kelas di masing-masing band yang menunjukan tingkat kegagalan per nasabah per 1 rupiah. Expected loss individual dapat dihitung dengan formulasi (2).

$$
\mathrm{nj}=\frac{E L j}{L j} .
$$

Keterangan :

$\mathrm{Nj} \quad=$ Expected loss individual dalam kelas ke- $\mathrm{j}$

Elj = Expected loss pada kelas ke- $\mathrm{j}$

$\mathrm{Lj} \quad=$ Kelas ke-j

Langkah 3: Perhitungan recovery rate dan real loss.

Real loss merupakan kewajiban nasabah tak tertagih akibat gagal bayar yang tergantung dari status nasabah yang bangkrut. Real loss dapat dihitung dari nilai recovery rate dan didapat melalui rumus 1-recovery rate. Nilai real loss berkisar dari angka 0 (terendah, artinya tidak ada kerugian sama sekali atau recovery rate $=100 \%$ ) sampai dengan 1 (tertinggi, artinya kerugian mencapai $100 \%$ atau recovery rate $=0 \%$ ). Nilai recovery rate memperhitungkan faktor agunan (jaminan), nilai baki debet yang dihapusbukukan dan lain sebagainya. Nilai recovery rate dapat dilihat dari tingkat NPF (nonperforming financing) perbankan sektor pertanian, yaitu persentase besarnya kegagalan nasabah (pihak peminjam) yang bergerak pada sektor pertanian dalam melaksanakan kewajibannya pada bank. Perhitungan recovery rate juga dapat dilihat dari nilai penghapusbukuan piutang yang memiliki kolektibilitas macet dengan melakukan penyitaan jaminan pembiayaan.

Langkah 4: Penentuan jumlah nasabah macet pada tingkat kepercayaan 96\%. 
Metode creditrisk+ menganalisis sejumlah kegagalan nasabah terdistribusi Poisson. Ada asumsi-asumsi yang menjadi dasar acuan dalam menentukan probability default seseorang dengan menggunakan distribusi Poisson, antara lain:

1. Probability default pada pembiayaan dalam suatu periode tertentu, misalnya 1 bulan maka untuk bulan-bulan lain nilainya akan sama.

2. Probability default pada pembiayaan nasabah dengan jumlah besar yang terjadi dalam 1 periode tidak bergantung dari jumlah default yang terjadi pada periode lain.

Rumus Poisson Distribution (Crouchy et al 2000) untuk mencari jumlah nasabah macet di setiap kelas ditunjukkan oleh formulasi (3).

$$
\alpha \mathrm{j}=\frac{m^{n}}{n !} \mathrm{e}^{-\mathrm{m}}
$$

Keterangan :

$\alpha \mathrm{j}=$ Nilai distribusi Poisson pada kelas ke-j

$\mathrm{e} \quad=$ Angka natural $(\mathrm{e}=2.718281828)$

$\mathrm{m}=\mathrm{nj}=$ Rata-rata jumlah nasabah default setiap kelas pada setiap band dalam 1 periode tertentu

$\mathrm{n} \quad=$ Jumlah ekspektasi nasabah macet $($ minimum $=0)$

$\mathrm{n} ! \quad=\mathrm{n}$ faktorial

Distribusi Poisson juga dapat dicari dengan menggunakan Minitab 14 sehingga dapat langsung ditemukan jumlah nasabah default pada tingkat kepercayaan $96 \%$.

Langkah 5: Perhitungan potensi kerugian pembiayaan.

Perhitungan potensi kerugian pembiayaan dapat dicari dengan menggunakan formulasi (4).

$$
\mathrm{PL}_{\mathrm{j}}=\sum_{\mathrm{j}=1}^{\mathrm{j}=\mathrm{n}} \sum_{\mathrm{i}=1}^{0}\left(\mathrm{~L}_{\mathrm{j}} \times \mathrm{n}(\alpha=5 \%)_{\mathrm{j}} \times \mathrm{RL}_{\mathrm{j}} \times \text { nilai } \text { band }_{\mathrm{k}}\right)
$$

Keterangan :

$\mathrm{PLj} \quad=$ Potensi kerugian kelas ke-j

$\mathrm{n}(\alpha=5 \%)_{\mathrm{j}} \quad=$ Jumlah nasabah yang diperkirakan macet berdasarkan distribusi

$$
\mathrm{RLj} \quad=(1 \text {-recovery rate }) \text { kelas ke-j }
$$

nilai band $_{\mathrm{k}} \quad=$ Nilai band $\mathrm{ke}-\mathrm{k}$

$\mathrm{n} \quad \quad=$ Jumlah kelas

$\alpha \quad=$ Jumlah band

Potensi kerugian di masing-masing band pada pembiayaan sektor pertanian kemudian dijumlahkan untuk mendapatkan total potensi kerugian pembiayaan sektor pertanian berdasarkan historis 1 tahun pada BPRS Amanah Ummah. 